\title{
Visualizing the Fight Book Tradition: Collected Martial Knowledge in the Thun-Hohenstein Album
}

\author{
Chassica Kirchhoff \\ The University of Kansas
}

Abstract: The Thun-Hohenstein album, long-known as the Thun'sche Skizzenbuch, is a bound collection of 112 drawings that visualize armoured figures at rest and in combat, as well as empty armours arrayed in pieces. The collection gathers drawings that span the period from the 1470s to around 1590. While most of the images were executed in Augsburg during the 1540s, the album's three oldest drawings date to the late-fifteenth century. Two of these works, which form a codicological interlude between the first and second quires, find parallels in the illustrations of contemporaneous martial treatises. This article traces the pictorial lineages of these atextual images through comparative analyses of fight books produced in the German-speaking lands, and considers how the representational strategies deployed in martial treatises inflected the ways that book painters and their audiences visualized the armoured body. This exploration situates a manuscript from which one of the drawings derives, Peter Falkner's Art of Knightly Defense, now in Vienna, within the Augsburg book painters' workshops that would later give rise to the Thun album. Finally, this study considers how the transmission and representation of martial knowledge in late fifteenth- and early sixteenth-century Augsburg contributed to the later depictions of armoured bodies that populate the album.

Keywords - Thun-Hohenstein album, fight books, Fechtbuch, codicology, manuscript studies, book painting, comparative analysis, image and memory, collecting

\section{INTRODUCTION: ECHOES OF MARTIAL KNOWLEDGE IN THE THUN ALBUM}

In a drawing executed in the style of the 1470s or 1480s, two pairs of horsemen clad in the elegant late-gothic plate armour of the fifteenth century, charge into combat with swords and maces raised (fig. 1). In the corner of the page, a pair of lightly dressed wrestlers grapple, each assuming a wide-legged stance to brace himself against his rival. In another drawing from the last decade of the fifteenth century a knight encased in meticulously depicted armour straddles his opponent, pinning him to the ground (fig. 2). 
The vanquished man's sword lies beneath his body, and he looks upward toward the victor's weapon, poised to deliver a final strike through the unfortunate man's open visor.

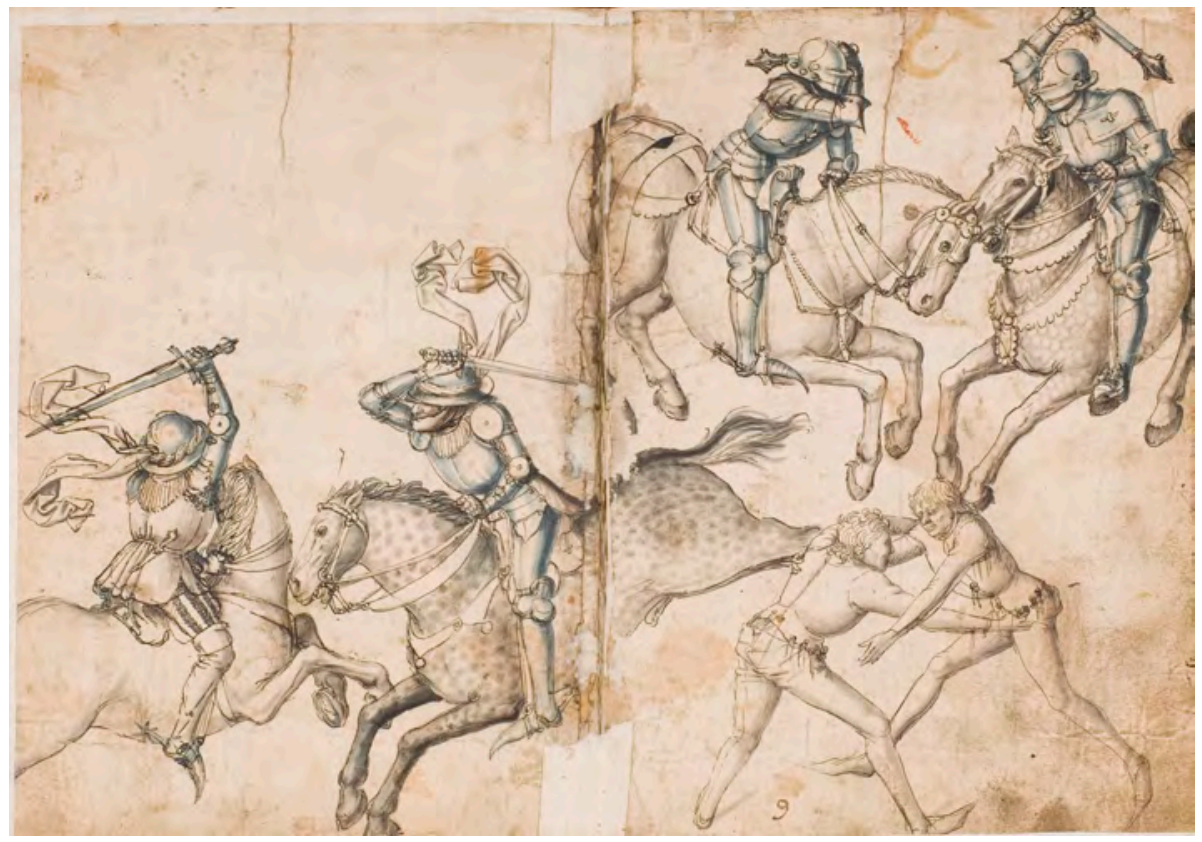

Fig. 1: Unknown Artist, Study of Three Pairs of Combatants, circa 1470s-1480s, ink and wash, Tbun-Hohenstein Album, Prague, Umèleckoprimyslové museum v Praze, GK 11.572-

B, folio 10v-11r.

These two bellicose images belong to a group of three fifteenth-century drawings that were inserted between the first and second quires of the Thun-Hohenstein album, likely during its compilation in the first decades of the seventeenth century. While drawings on paper manufactured in the 1530s or 1540s form the surrounding leaves, the style of these three images, each drawn by a different hand, suggests that they date to the second half of the fifteenth century. ${ }^{1}$ As the oldest works of art to be included in the Thun album,

* This study was made possible by research funding from the Renaissance Society of America and the University of Kansas, as well as the generous assistance of Tereza Janoušková and the staff at the Uměleckoprůmyslové museum v Praze. I am grateful to Pierre Terjanian, Stefan Krause, and Daniel Jaquet for their thoughts on my explorations of the Thun album's history and meaning, as well as to Alvaro Soler de Campo of the Real Armería, Günther Hägele of the Universitätsbibliothek Augsburg, and the gracious staff members of the Bayerische Staatsbibliothek and Österreichische Nationalbibliothek. Finally, I am deeply indebted to Anne D. Hedeman and Stephen H. Goddard for their advice and editorial feedback during the development of this study. 
they predate the images that surround them by up to five decades and represent fifteenthcentury pictorial and literary genres that established visual languages of the armoured body that resonate through the album's later drawings.

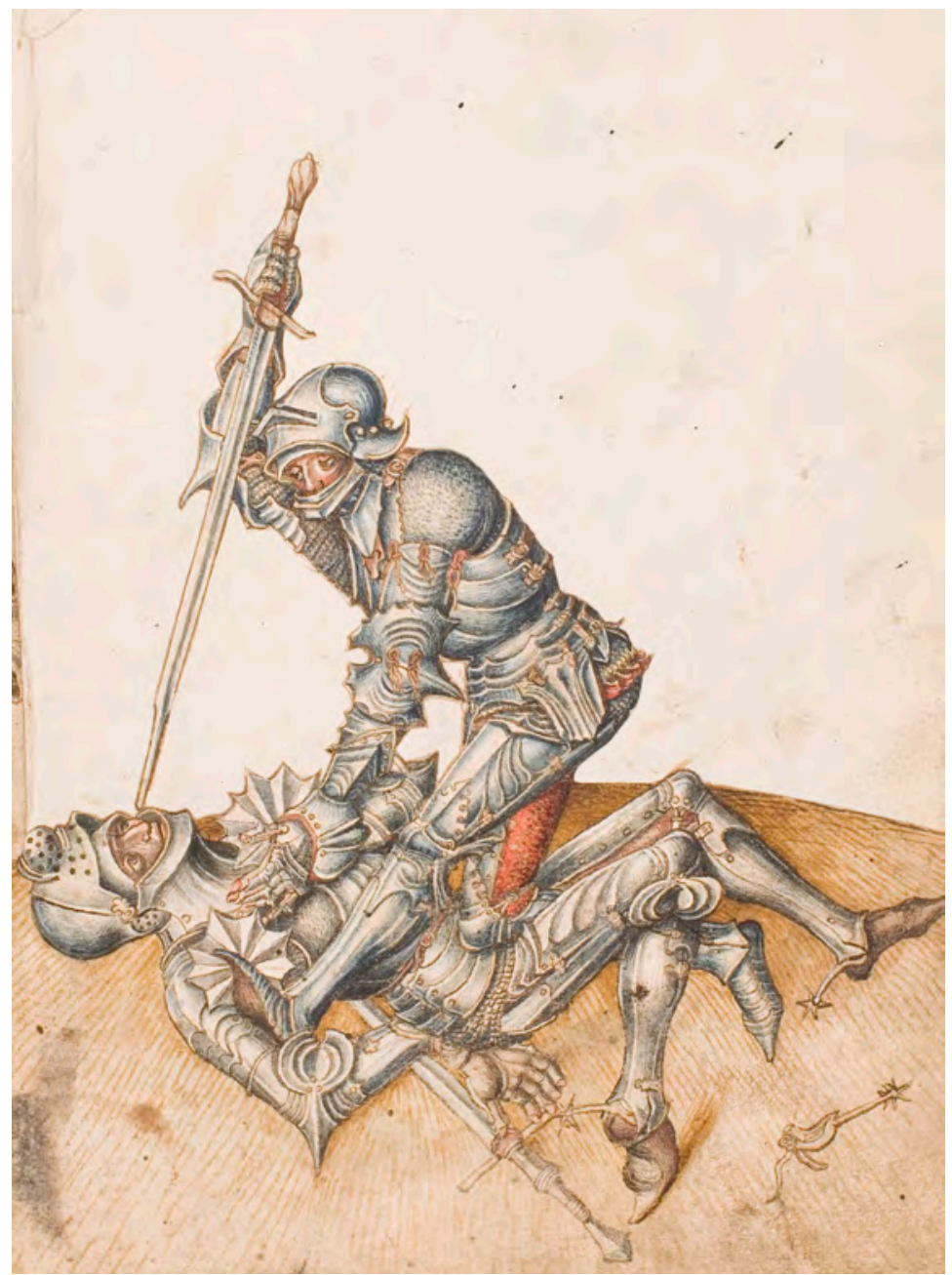

Fig. 2: Unknown Artist, Subduing an Opponent, after circa 1495, ink and wash, ThunHohenstein Album, Prague, Uměleckoprimyslové museum v Praze, GK 11.572-B, folio 12r.

The first and third images in the album's group of fifteenth-century drawings derive their imagery from so-called martial manuals, commonly known as Fechtbücher (fight or fencing books) in the German-speaking lands. This genre combined intellectual frameworks

1 Thun-Hohenstein Album (GK 11.572-B). See also, Terjanian, “The art of the armorer," 328, 330; Briquet, Les filigranes, vol. 3, 471, 517. For more on these watermarks, see note three. 
surrounding martial skill, military science, and didactic literature. However, it remains at the margins of current art-historical research. Fight books and literature that included martial knowledge, such as mirrors for knights, household compendia, or masters of arms' books, were ubiquitous in the circles that created and viewed drawings like those collected in the Thun album. Because of this ubiquity, consideration of fight books helps to show how the visual and textual traditions that shaped the Thun album drawings imbued their depicted armoured bodies with meanings familiar to their audiences. Through this resonance, the album's fifteenth-century drawings became capable of functioning as mnemonic prompts that could incite viewers' recollections of martial knowledge. Analyses of these three images demonstrate how the armoured body becomes a vehicle for memory, a theme that unites the diverse artworks collected in the album. Consideration of these three drawings between the album's first two quires and their broader codicological context within the album, alongside related contemporary artworks, offers insights into the ways that viewers and-perhaps-the codex's anonymous compiler understood the drawings that make up the bound collection.

\section{I.1. The Thun-Hohenstein Album: (Re)Introducing a Complex Bound Collection}

Despite their disappearance just before the Second World War, the two enigmatic codices known widely as the Thun "Sketchbooks," which I call albums in acknowledgement of their accretive nature, remained important sources and objects of speculation for historians of arms and armour throughout the twentieth century. Beginning in 2011, my first forays into the history of one of these codices included analysis of photographsnow housed in the Maximilian Museum, Augsburg - that were considered the only vestiges of the lost volumes. ${ }^{2}$ Dr. Pierre Terjanian's rediscovery of the codices in 20102011 made it possible for me to reintegrate the drawings within the artistic and sociocultural contexts that shaped their creation, collection, and reception. The study from which this article derives is the first to deeply interrogate the drawings' pictorial lineages and their retrospective representation of particular armours. I situate the drawings and the bound collection that they comprise within a culture of remembrance, or Erinnerungskultur, that re-constructed Emperor Maximilian I (1459-1519) and the martial culture that surrounded him in the imaginary of the mid- and late-sixteenth century and that presented his successor, Charles V (1500-1558), as part of a powerful martial lineage. Further, art-historical reflection on case studies, such as the three drawings that are the foci of this article and the bound collection in which they take their place, significantly expands Terjanian's foundational assertion that the Thun album is not a transparent record celebrating the Helmschmid family of armourers' work for illustrious patrons. Rather, the codex collects representations of armoured bodies and disassembled armours that were themselves drawn from diverse graphic sources, and recombines them into

2 Augsburg, Maximilianmuseum, Grafische Sammlung file FII, Hans Stöcklein. 
meaningful juxtapositions that manifested the recollections or associations of the early modern compiler.

The Thun album is a heterogenous bound collection of 112 drawings. They include thirtysix performative representations of armoured figures both at rest and in combat, as well as seventy drawings of empty armour arrayed in pieces and eight portrayals of elaborately armoured horses. The collection encompasses the work of at least eight draftsmen working over a period that extends from the 1470 s to the 1590 s. A significant majority (101) were drawn by Augsburg artists between the late 1530s and late 1550s. A first set of sixty-one ink and gouache images on watermarked paper used in Augsburg during the 1540s appears to have been executed by an artist (Artist A) familiar with both armour made for Emperors Maximilian I and Charles $\mathrm{V}$ and its depictions in artworks associated with them. ${ }^{3}$ Thirty of Artist A's drawings portray actual surviving armours crafted by the innovative armourers of Augsburg's Helmschmid family and many more formally echo their work. Indeed, most of the drawings in this group retrospectively depict armours produced from the 1480 s through the 1520 s, during and immediately after the lifetime of Maximilian I. A second set of forty drawings bears many of the same watermarks, and was likely executed in Augsburg during the 1540s and 1550s. This group contains less precise, somewhat clumsy drawings by another anonymous artist (Artist B). Artist B's images seem to copy depictions of armour owned by Charles $\mathrm{V}$ and recorded in his Inventario Illuminado, a sumptuously illustrated inventory of his possessions drawn up in Augsburg between 1544 and 1558. ${ }^{4}$ The earliest of the eleven drawings not attributable to these artists - three works dated to the last quarter of the fifteenth-century on the basis of style and comparative analysis - are concentrated between the album's first and second quires. This codicological interlude is the focus of the present article.

\footnotetext{
${ }^{3}$ Briquet, Les filigranes, vol. 3, 471, 517. A significant majority (105 of 112) of the drawings contained in the album appear on paper whose watermarks from the 1530s and 1540s. 33 bear Briquet watermark 8771. It first occurred in Bavaria in 1532 and was in documented use in Augsburg from 1545-1548 and occurs throughout drawings by both Artists A and B, who executed sixty-one and forty of the works, respectively. Terjanian posited that this may suggest that either one or both artists used the paper when is was already bound. However, this seems unlikely given the lack of precedents for such a process and the absence of material evidence, such as the significant smudging of adjacent pages that would occur as an artist added new work to the album. Rather, the codex is one of many Sammelbände, or collected volumes, that originated from early modern Augsburg. In addition to the watermarks on works by Artists A \& B, two bifolios bear marks similar to Briquet type 9908 or 9909, which were used in Augsburg during the 1530s.

${ }^{4}$ Inventario Illuminado, 1544-1558 (N.18a-b); Terjanian, "The art of the armorer," 306-320. Terjanian divided the 112 drawings of the Thun album into three groups, of which "A" and " $B$ " were comprised of sixteenth-century works created by these two main hands. Although the Inventario Illuminado has never been published in its entirety, José A. Godoy of the Real Armería is conducting ongoing work on a complete scholarly edition of the inventory. My research on the Thun album included cataloging and examining the structures of both Inventario volumes, which were rebound around 1900 .
} 
The codices' provenance between their compilation in early seventeenth-century Augsburg and their entry into the baronial library of the Thun-Hohenstein family at Schloss Tetschen (Děćín) in Bohemia during the eighteenth century remains unclear. Alexander Freiherr von Reitzenstein suggested that drawings that inhabited the earlier codex belonged to Leonhard IV von Harrach, Count of Ruhrau (1514-1590), the Obrist Stallmeister, or Master of Horse and Armour, for Hapsburg lands above the river Enns. ${ }^{5}$ However, von Harrach died at least two decades before the album was compiled into its current form, so his cannot be the "Obriststallmaistery" to which an inscription on the front flyleaf of the album refers. Furthermore, the atextual Thun album's thematic juxtaposition of unrelated, temporally diverse armours, as well as its dispersal of images of the same armour or garniture across separate quires, and its representation of armours that would have been housed in far-flung repositories by the late-sixteenth century all preclude its functionality as an Obrist Stallmeister's inventory or reference book. ${ }^{6}$

The possibility that at least some of the drawings may have passed through the collection of the Fugger family of Augsburg deserves further investigation beyond the scope of this study. For instance, Johann (Hans) Jakob Fugger (1516-1575) was an avid historian who commissioned expansive, illustrated histories of both his own illustrious family and the Hapsburg dynasty. Hans Jakob Fugger's projects shared not only stylistic characteristics and contexts of origin with the Thun album drawings, but also the album's commemorative themes. ${ }^{7}$ During the second half of the sixteenth century, the Fuggers amassed expansive collections of Augsburg-made manuscripts and artworks that presented the armoured body as a representation of power, martial skill and knightly identity. ${ }^{8}$ Despite these tantalizing possibilities, the specific origins of the Thun album

5 Reitzenstein, “Das Thun'sche Plattnerbuch a/2," 93; Terjanian, “The art of the armorer,” 301.

${ }^{6}$ Many possible Obrist Stallmeister may be found at the imperial court under Emperor Matthias (1557-1619) or Ferdinand II (1578-1637), or even among the aristocratic masters of horse who emerged from the Fugger family of Augsburg during the early-seventeenth century. Figures who deserve deeper investigation include Anton Fugger the Younger (1563-1616), who served as master of horse to the ducal house of Bavaria (whose Augsburg connections intersect with the origins and context of use of the album's binding paper) or, perhaps, Bruno III, Graf von Mansfeld, imperial Obrist Stallmeister from 1615 to 1644.

${ }^{7}$ For instance, Johann Jakob Fugger and Clemens Jäger, Ehrenspiegel des Hauses Österreich, 1555-59 (Munich, Bayerisches Staatsbibliothek Cgm. 895-896); Johann Jakob Fugger, Das Ehrenbuch der Fugger, circa 1560, (Munich, Bayerisches Staatsbibliothek Cgm. 9460). Fabian and Bubenik, Die Fugger im Bild, 49-54; Friedhuber, "Der 'Fuggerische Ehrenspiegel' als Quelle zur Geschichte Maximilians I," 107.

8 Confession, Court Records, Inventories, and Sales-Records of Paulus Hector Mair (Augsburg, Staats- und Stadtarchiv, Inventar Urgichten 262, 1579-1580). For example, many of the martial manuals commissioned and collected by the Patrician and fencing enthusiast, Paulus Hector Mair, were acquired by "Johann Fugger" (perhaps Hans Fugger, 1531-1598) and by Marx Fugger (1529-1597) following Mair's execution in 1579. See also Welle, “...und mit der recbten faust ein mordstuck," 22. 
drawings and their provenance during the late-sixteenth and seventeenth centuries remain mysterious.

Bookplates pasted onto both albums' front flyleaves testify that Joannes Joseph František, Count of Thun (1711-1788), owned the two bound collections during the eighteenthcentury, and both of the albums of armour remained in the Thun-Hohenstein library at Schloss Tetschen after his death. ${ }^{9}$ In the Tetschner Bibliothek, the volumes were cataloged under the Latin title Imagines Catafractorum, or Images of Armour, which still appears on the blank parchment spine of the earlier album. ${ }^{10}$ By 1888 , the codices' images of armours associated with Holy Roman Emperors Maximilian I and Charles V prompted the Viennese art historian, Quirin von Leitner to publish seven images from both albums in the journal of the imperial collections. ${ }^{11}$ In 1924, Hans Stöcklein, director of the Bayerisches Armeemuseum, transported the codices to Munich, where he had large portions of the earlier album photographed. The resultant black-and-white glass negatives, annotated with terse descriptions by Stöcklein, found their way into the collection of the Maximilian Museum in Augsburg. ${ }^{12}$ The Thun-Hohenstein family sold Schoss Tetschen to the Czechoslovakian government in 1932; in the same year, representatives of the count offered to sell the two codices of Augsburg armour to the Maximilian Museum, without success. ${ }^{13}$ The volumes were last documented at the castle in 1936, when the building was converted into military barracks. The German occupation of the Sudetenland began in 1938, and Schloss Tetschen was captured by the German army and recaptured again by Czechoslovak forces during the course of the Second World War. The contents of castle's library were presumed to have been destroyed or lost in this tumultuous period until the codices' reemergence following Terjanian's discovery.

\section{I.2. Codicological Overview}

As is the case with so many martial sources, both Thun-Hohenstein albums are deceptively humble volumes; the first album is bound in blank parchment that is riddled

9 Thun-Hohenstein Album (UPM, GK 11.572-B), flyleaf and attendant archival documents housed with the codex.

10 Gamber, "Der Turnierharnisch zu Zeit König Maximilians I."

11 Leitner, "Artistisches Quellenmaterial aus der Gräfl. Thun-Hohenstein'schen FideicommissBibliothek in Tetschen."

12 Augsburg, Grafische Sammlung, file FII. My thanks to Dr. Christoph Nicht for facilitating my access to these photographs at the outset of this project, in July 2011.

13 Letters preserved alongside the Thun-Hohenstein Albums (GK 11.572-A and B), exchanged between representatives of the Count Thun-Hohenstein and the Maximilian Museum from MarchMay, 1932. 
with lacunae that may suggest reuse from an older source. ${ }^{14}$ All of its eighty-one folios, which measure $307 \mathrm{~mm}$ high and $220 \mathrm{~mm}$ wide on average, were once loose sheets; these were glued onto the tips of short leaves that comprise the volume's nine quires. Elaborate, double-eagle watermarks that appear on the short tips along the gutter, on the guard strips that stabilize and extend the outer, top, and bottom edges of some pages, and on the front and back flyleaves suggest that the codex's current form originates from the first three decades of the seventeenth century. ${ }^{15}$ Six drawings that span the openings of single bifolios in the second quire were folded in half and glued to single paper tips at their centers. ${ }^{16}$ At least two drawings - the fifteenth-century image of armoured combat on folio $12 \mathrm{r}$ (see fig. 2) and a drawing of a disassembled set of armour from the last decades of the sixteenth-century-were cut as silhouettes from their original sheets and pasted onto paper that is congruent with the two largest groups of images. ${ }^{17}$

The first five quires of the album contain primarily armoured figures and barded horses, while the last four quires of the album comprise mostly drawings of disassembled pieces of armour arrayed across the page. In the first quire, the first four rectos depict four seated portraits of princes of the house of Habsburg. ${ }^{18}$ These drawings are based on woodcuts from Hans Burgkmair the Elder's Genealogy of Maximilian I, created between 1509 and 1512. Because Burgkmair's Genealogy never circulated outside of the imperial court or Burgkmair's immediate artistic milieu, it is likely that the draftsman, Artist A, had access to one or both of these circles. Furthermore, these four princely portraits form a kind of pictorial preface to the first quire's images of figures clad in sumptuous armours for the tournament and procession.

Other distinctive groups of images dominate the first five quires. Between the first and second quires, an inserted bifolio forms the physical core of the group of three fifteenthcentury drawings that are the focus of the present article. Eight of the ten images that the

14 Thun-Hohenstein Album (2) (UPM GK 11.572-A) is bound in a reused parchment leaf from a thirteenth- or early fourteenth-century polyphonal or antiphonal.

15 These watermarks are related, but not identical, to earlier Briquet types 266 and 267 (from the 1570 s through the 1610s). Briquet, Les filigranes, vol. 1, 33. Similar marks appear in works created in Augsburg during the 1620s. See Piccard-Online, <https://www.wasserzeichenonline.de/wzis/?ref=DE4860-Rep_II $29 \quad 20>$

16 Thun-Hohenstein Album (UPM, GK 11.572-B), fols. 13-24. Because of the ways that three single tips support bifolios in this part of the album, the number of folios in the second quire seems uneven.

17 Thun-Hohenstein Album (UPM, GK 11.572-B), fols. 12r and 56r. All foliation uses Terjanian's new foliation, rather than the misleading pencil foliation likely added by Stöcklein or the somewhat confusing sixteenth-century numbers painted in ink on the rectos of many of the leaves, which may or may not designate binding order. See Terjanian, "The art of the armorer," 302-03.

18 These portraits represent Emperors Maximilian I and Charles V, Louis, King of Hungary (150626), and Philip the Fair, Duke of Burgundy and King of Castile (1478-1506). 
second quire contains depict riderless horses in elaborate caparisons or bards, while a significant portion of the third quire visualizes equine armours and saddles drawn from the illuminated inventory of Charles V. Two of the remaining four images in this quire represent mounted figures and armoured steeds. The rectos of the leaves that comprise the album's fourth and fifth quires depict standing figures in sumptuous, oftenrecognizable armours. Additional images of disassembled armours, many of which relate to specific forms of tournament combat, follow these drawings. Pages populated with disassembled sets of armour components and arrays of empty helms fill the remainder of the codex. The album's organization, which privileges performative and static images of the armoured body over depictions of empty armour, suggests ways that period viewers invested armour and its representations with meaning, as sites of both identity and memory.

This study combines codicological examination with comparative visual analyses of pictorial style, which consider how details of draftsmanship manifest the practices deployed by individual book-painters, workshops, and local or regional artistic networks. ${ }^{19}$ Such an approach reveals the album to be a rich source for the ways artists represented martial material culture. It also suggests the meanings resident in the drawings for viewers indoctrinated into the martial culture of the Holy Roman Empire, which, like many systems of material and intellectual exchange, united urban and courtly audiences. As Stefan Krause and Christof Kaindel demonstrated in their article on the transmission of mid-fifteenth-century fight book imagery through prints by the Master E.S., close observation of the representation of gestures or the delineation of bodily forms shows how fight book illustrations permeated other facets of contemporary visual culture. ${ }^{20}$

As an accretive compilation of images related to both the representation of the Habsburg dynasty and the luxury armours produced for this imperial milieu, the Thun album shares many characteristics with bound collections produced in Augsburg during the midsixteenth century. Comparative analyses of these codices not only reveal themes that converge in the particular intellectual culture of the imperial free city, but also offer clues that suggest potential contexts whence the individual drawings that the album collects originated. Furthermore, such comparison identifies the Thun album not as an enigmatic, outlying unicum, but as a manifestation of vibrant early modern practices of commemoration and collecting centered around martial identities.

${ }^{19}$ For a conceptual discussion of the role of stylistic analysis in art-historical inquiry see Neer, "Connoisseurship and the Stakes of Style."

20 Stefan Krause and Christoph Kaindel, "Das Großen Kartenspiel des Meisters E.S." 


\section{COMPARATIVE CONNECTIONS AND INTERPRETIVE PATHWAYS}

\section{II.1. A Martial Compendium in a Single Opening: Folios 10r and 11v}

A dynamic drawing that spans a single bifolio that is affixed to a short, seventeenth century paper tip along its central fold forms the physical and conceptual core of the group of album's fifteenth-century pages. ${ }^{21}$ Long considered the oldest image in the codex, the drawing's style is consistent with draftsmanship and printed imagery common during the 1470s and 1480s. ${ }^{22}$ This composite image contains six figures-three pairs of differently armed men-who engage in mounted combat or grapple on foot. While each pair of sparring figures evokes a particular category of combat or martial sport that appears in contemporaneous martial manuals, their amalgamation into a single composition has no known precedent in the surviving body of fight books. Together, these three sets of fighters visualize integral facets of martial knowledge that would have been an important part of training for knightly, princely, and non-noble viewers alike.

The pair of wrestlers who assume wide-legged, firmly planted stances near the drawing's lower right corner derive from the tradition of Ringenkunst, or the art of grappling. ${ }^{23}$ While wrestling techniques were sometimes disseminated in specialized volumes, known as Ringerbücher, grappling was also a foundational skill for nearly all other types of combat, whether unarmoured or encased in steel, on foot or mounted. Thus, the wrestlers who face off in the Thun album correspond with illustrations in numerous martial manuals. Images of grapplers from the so-called Codex Wallerstein, offer comparisons from the 1470s. Other fight books from the fifteenth century contain parallel representations of wrestlers. These include two versions that the Fechtmeister, or fencing master, Paulus Kal dedicated to Ludwig "the Rich," Duke of Bavaria during the late 1460s and 1470s and five fifteenth-century volumes connected to Hans Talhoffer. The version of Talhoffer's treatise that was created in Swabia for Count Eberhadt von Württemberg in 1467 (fig. 3) contains particularly striking stylistic similarities to the Thun drawing. ${ }^{24}$ In both volumes, the anonymous draftsman delineated the grapplers' dynamic bodies in loose yet confidently fluid strokes that enclose volumes articulated with subtle washes.

\footnotetext{
21 UPM GK 11.572-B, folios 10v-11r.

22 Gamber, "Der Turnierharnisch zu Zeit König Maximilians I," 3.

23 Terjanian, "The art of the armorer," 328.

${ }^{24}$ Hans Talhoffer, Fechtbuch for Count Eberhardt of Württemberg, 1467 (Cod. icon 394a), 190r. 


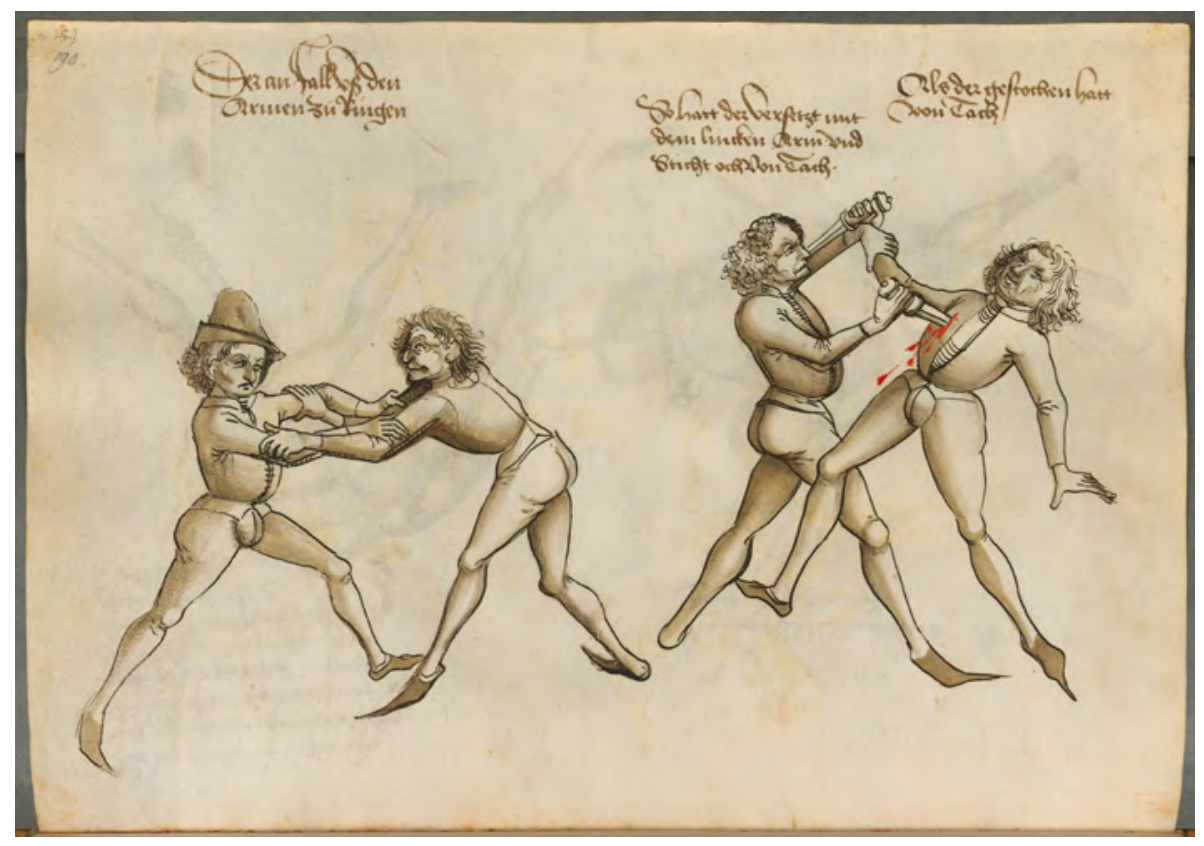

Fig. 3 The Attack of Wrestling from the Arms (Der anfall vsz den Armen zu ringen), Hans

Talhoffer Fechtbuch for Eberhardt of Württemberg, Bayerische Staatsbibliothek, Cod. icon. 394 a, folio $96 r$.

In many of these examples from Kal and Talhoffer's treatises, the wide-set stances of the grapplers, who lean toward one another while each man reaches outward to keep his opponent at arm's length, appear at or near the beginning of the masters' sections on wrestling. These comparisons reveal how the Thun drawing represents a foundational maneuver within the art of grappling. Furthermore, they underscore the drawing's relationship to modes of representing martial knowledge popular in Swabia and Bavaria during the last third of the fifteenth century.

The two wrestlers not only embody the basis of martial skill in unarmed grappling; they also visualize the fleshy vulnerability of the unarmoured body through their juxtaposition with the mounted warriors with whom they share the page. The men wear only their shirts and breeches, which are held up by laces that connect them to the shirts' hems. Such minimal clothing appears throughout the fight book genre, which envisions the appearance of students at practice. The wrestlers' wavy hair seems to move about with their maneuvers, and, while one man's face is only partially visible, his opponent wears an expression of concentrated determination. Their facial physiognomies-with slightly bulbous noses and wrinkles that extend from eyes narrowed in concentration-recall the often-coarse visages that populate many illustrated fight books, especially those associated 
with Talhoffer, whose treatises often claimed that the master had modeled the techniques himself. 25

On the left side of the drawing, across the gutter from the wrestlers, two riders charge toward each other with swords raised. They are lightly armoured in variations of the style worn by light cavalry during the second half of the fifteenth century. The long-legged swordsman who rides the dappled grey steed wears full leg armour that terminates in elegant, pointed sabatons, or foot defenses. This steel footwear echoes the elongated Schnabelschube, the long, beak-shaped shoes popular throughout the late fifteenth century. The crease between his cuisses, or thigh guards, and the flexible, hinged faulds at the bottom of his breastplate is protected by finely wrought triangular tassets. The swordsman's arms are also completely enclosed in articulated plate, and his fingered gauntlets easily flex to grip the hilt of his upraised weapon. Beneath his helmet, he wears a bevor to protect his chin and throat. The steel surface of this component is covered in fabric, similar to the bevor worn by a rider, armoured in the style of the 1480 s, who was retrospectively depicted by Thun Artist A (fig. 4) during the 1540s. ${ }^{26}$

The thighs of the rider nearest the page's right edge are not encased in steel plates like those of his opponent; instead vertical strips of mail protect them from slashing blows (fig. 5). ${ }^{27}$ This rider's back turns toward the viewer, revealing the dagger that is tucked into his belt and the finely wrought hinges of the canons that enclose his upper and lower arms. Beneath his doublet, the horseman wears a mail shirt, and his head, like that of his opponent, is protected by a steel war hat, a type of brimmed helmet popular during the middle third of the fifteenth century.

\footnotetext{
${ }^{25}$ Hans Talhoffer, Fechtbuch (MS Thott.290.2º ), fol. 103v; Munich, BSB 394a, folio 136v.

${ }^{26}$ Thun-Hohenstein Album (GK 11.572-B), fol. 8r.

27 Terjanian, “The art of the armorer," 328. 

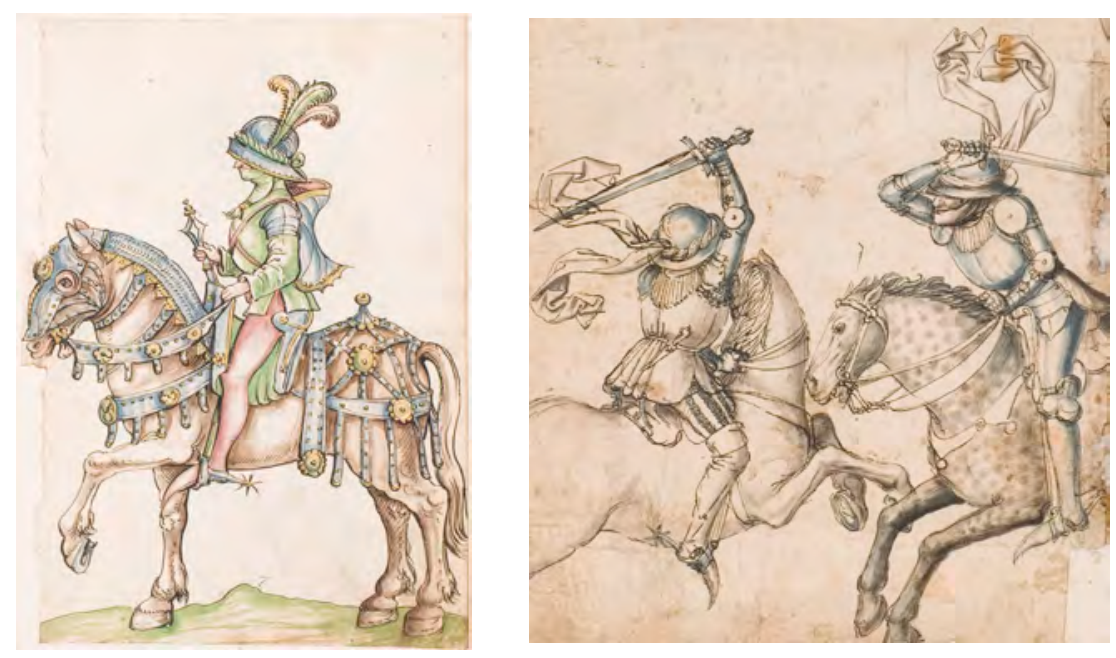

Fig. 4 (left): Thun Artist A, Rider armoured in the style of circa 1480 riding a horse lightly armoured in the style of circa 1510, circa 1530-1540, Thun-Hobenstein Album, Prague,

Uméleckoprimyslové museum v Prąe, GK 11.572-B, folio $8 r$.

Fig. 5 (right): Unknown Artist, Study of Three Pairs of Combatants (detail), circa 1470s1480s, ink and wash, Thun-Hohenstein Album, Prague, Umèleckopriomyslové museum v Praze, GK 11.572-B, folio 10v.

Like the figures who grapple on the facing page, these cavalrymen parallel the illustrations that populate contemporaneous fight books. Once again, Talhoffer's fight book from 1467 offers analogous content with striking stylistic parallels. Although the mounted swordsmen who gallop across the Munich manuscript's pages do not wear leg armour, their clothing and war hats echo those worn by the Thun riders. Furthermore, their grisaille forms and inky outlines recall the style of the Thun drawing. Talhoffer's personal manuscript, now in Copenhagen, offers additional comparative examples from the 1450s. This volume's illustrations of mounted grappling and of a mounted lancer and crossbowman each visualize figures whose clothing and armour resonate with the mounted swordsman in the Thun opening, down to the fabric-covered bevors that the figures in each illustration sport.

The heavy horsemen in the drawing's upper right are more tightly encased in reinforced plate armour than the swordsmen with whom they share the opening. The riders brandish flanged maces similar in form to both functional and ceremonial examples from the late fifteenth century. Heavy weapons, such as maces, poleaxes, and war hammers, intended to deliver both blunt force and piercing damage were often more effective against steel plate armour than swords, and they therefore waxed in popularity throughout the fifteenth-century. ${ }^{28}$ Though they developed in response to armoured combat, such arms

${ }^{28}$ Capwell, Edge, and Warren, Masterpieces of European arms and armour in the Wallace Collection, 60. 
became intimately associated with knightly identity. Once again, Artist A's courtly figure, armed in the style of 1480 and carrying a flanged mace in procession or triumphal entry, demonstrates this practice (see fig. 4).

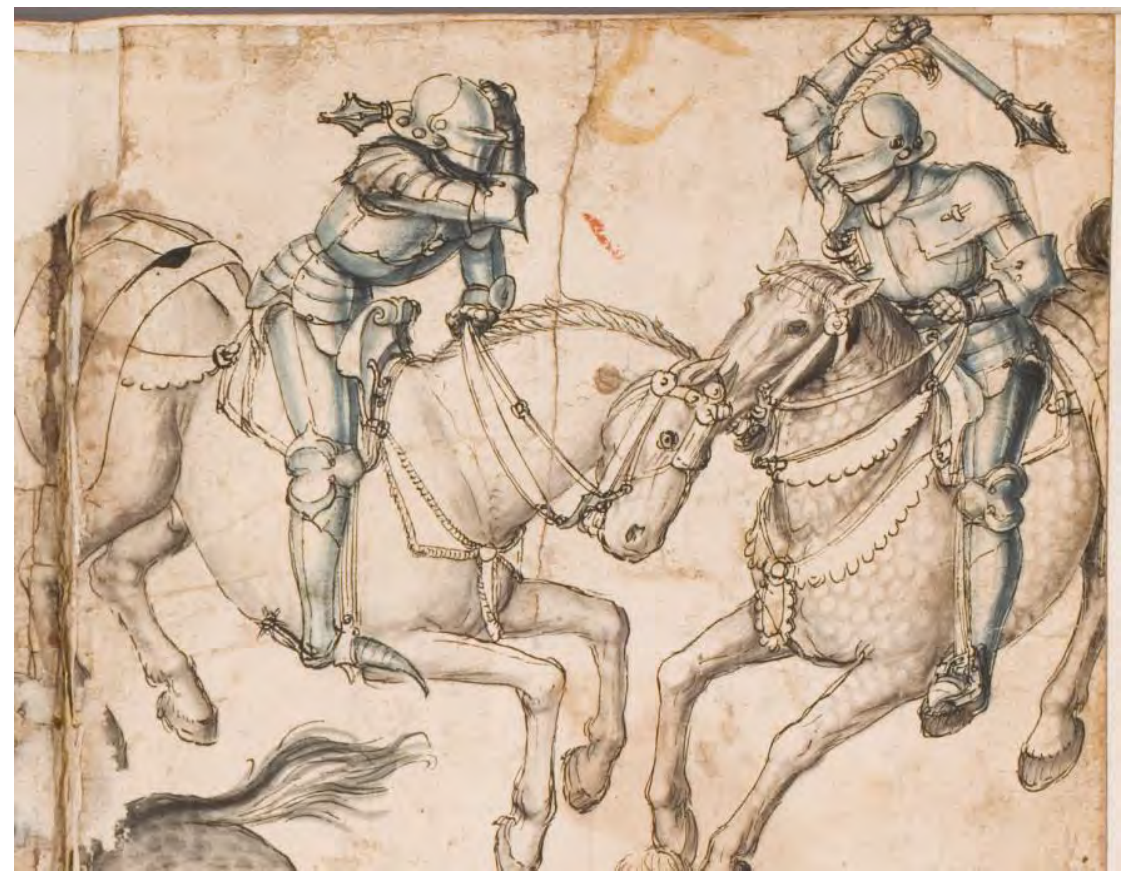

Fig. 6: Unknown Artist, Study of Three Pairs of Combatants (detail), circa 1470s-1480s, ink and wash, Thun-Hohenstein Album, Prague, Umèleckoprimyslové museum v Praze, GK 11.572-B, folio 11 r.

The mace-wielding heavy cavalrymen are finely armoured (fig. 6); each wears a visored sallet, a streamlined style of helm with a pivoting faceplate. The riders' sabatons and couters, or elbow plates, have been formed into attenuated points that are characteristic of late gothic armour. The rider who charges from the left on a pale horse wears pauldrons (shoulder defenses) with elegant, scalloped edges over his shoulders, while his opponent's left shoulder is further protected by a reinforcing plate that is bolted to the pauldron beneath. The right-hand rider, whose helm is crested with a white plume, may also wear a reinforcement over his left elbow, suggested by its large profile and prominent rivets or bolts. ${ }^{29}$ Such additional layers of protection were concentrated on the left side, which received the majority of blows delivered by an assailant's right hand.

29 Though the left rider's left pauldron, which would be the reinforced side, is not visible, period readers may have read both combatants as properly equipped for mounted fights with maces, when reinforcing plates would be very helpful for both men. 
Although there are no directly analogous representations of mounted, armoured combat with maces in the extant body of fight books from the German-speaking lands, the heavily armoured figures at the top of the opening have counterparts in martial treatises that included sections on equestrian combat in armour. ${ }^{30}$ For instance, the Talhoffer treatise in Copenhagen contains images of similarly armoured mounted swordsmen. However, none of the drawings that illustrate surviving martial treatises approach the meticulous depiction of armour that the anonymous draftsman who created the opening of the album accomplished in his visualization of the heavily armoured riders. This observant depiction of armour in motion likely informed Ortwin Gamber's incorrect yet evocative attribution of the drawing to an armourer, but this pair of mounted figures is not the only image in the album that unites the visual language of fighting treatises with exceptionally vivid representation of the arms and armour that comprised martial material culture.

\section{II.2. Invoking the Fechtmeister's Art: The Thun album and the Kunst zu Ritterliche Were}

The final fifteenth-century image included in the Thun album (see fig. 2) was trimmed along the outlines of the figures it portrays and pasted onto the blank recto of a sixteenthcentury drawing. This drawing depicts a fully armoured swordsman pinning his armoured opponent to the ground. He raises his weapon, poised to thrust his blade through the helpless man's open visor. The apparent victor in this fray has also pushed back his visor, and gazes downward over the bevor that obscures his lower face. One of the leather straps of his breastplate traverses his left shoulder beneath the curving tail of his sallet, a common feature designed to protect the nape of the neck. Because he wears mail rather than pauldrons on his shoulders, the red points, or leather laces, that tie the steel plates of his armour onto the arming garments beneath are visible along the edge of the rarebraces that enclose his upper arm and on the exceptionally pointed couter that encases his elbow. The victor holds his opponent firmly to the ground with a hand encased in a finely articulated fingered gauntlet and a foot that is protected by a pointed sabaton. He seems to have lost one of his spurs in the struggle, and it lies on the ground to the figures' right. Helpless, the fallen knight stares up with an expression of dread through the visor of his strikingly archaic bassinet-style helm-a variation that recalls the so-called "Hound's Skull" form popular during the early- to mid-fifteenth century. ${ }^{31}$ The man's

\footnotetext{
30 Although maces appear in martial manuals from the German vernacular tradition of the fifteenth and sixteenth centuries, they are most often used on foot in combination with long shields (or pavises) that may have additional spikes or hooks. In these contexts, the maces-which are closer to wooden clubs than to the flanged maces used against armoured opponents - are wielded by unarmoured or minimally armoured fighters, who are often presented in the context of a judicial duel.

31 It is noteworthy that the same style of helm (which also echoes forms crafted by north-Italian armorers in the first half of the 1400s) appears in the so-called Gladiatoria manuscripts of the early fifteenth century (see Gladiatoria, circa 1430, MS KK5013) and, later, in combination with salletActa Periodica Duellatorum 6(1), 2018 
armoured right arm is twisted awkwardly beneath his body as he lays upon the blade of a sword that seems to have just fallen from his open right hand. His left hand, encased in a mitten gauntlet, is barely visible as it grips his opponent's forearm; its red lining and brass rivets delineate his fist, though the grey steel of each man's armour visually merges into a single surface.
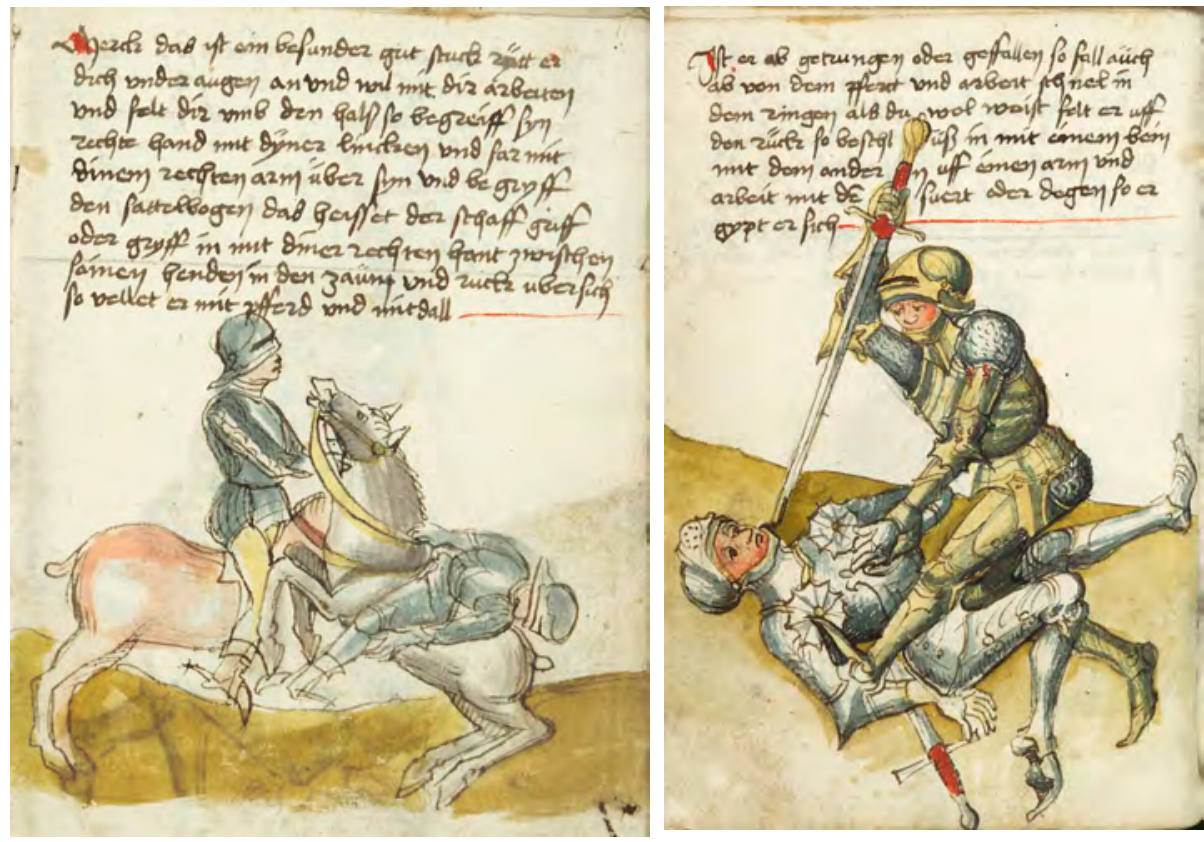

Figs. 7 (left) and 8: Unknown Augsburg book painter, Unhorsing an Opponent (left) and Subduing an Opponent, from Peter Falkner, The Art of Knightly Defense, Vienna, Kunsthistorisches Museum, KK 5012, fols. 72r-v.

The violent and fragmentary depiction of two figures locked in combat on Thun folio $12 \mathrm{r}$ bears a striking resemblance to the final illustration of a fight book written in the $1490 \mathrm{~s}$ by Peter Falkner, a fencing master and captain of the illustrious guild of swordsmen, the Marxbrüder or Brotherhood of Saint Mark (fig. 8). The Kunst zu Ritterliche Were, or The Art of Knightly Defense, includes instructional verses and illustrations on unarmoured fencing with a longsword and Messer (a single-edged sword), as well as foot combat with daggers, staves, shields, and clubs. ${ }^{32}$ The treatise also describes strategies for fighting on horseback

clad figures in sections of Kal's Fechtbuch for Ludwig of Bavaria-Landshut and in manuscripts collected by Paulus Hector Mair. See Kal, Fechtbuch for Ludwig of Bavaria (Cgm 1507). This lends weight to the suggestion that $\mathrm{Kal}$ functioned as an important model for Falkner, who-in turninfluenced Augsburgers like Jörg Wilhalm Hutter and, ultimately, Mair.

${ }^{32}$ Falkner, Kunst zu Ritterliche Were, circa 1491-1495 (KK 5012); Tobler, Captain of the Guild, 1-3. This connection was also observed by Nicolas Baptiste prior to the Terjanian's publication of the Acta Periodica Duellatorum 6(1), 2018 
with polearms, lances, and swords. The final page of Falkner's manual presents an image of a man in gilded armour who has thrown his opponent to the ground and appears to prepare to end his life with a sword thrust to the face. This image represents the end of the author's lesson on mounted combat in armour, and follows a depiction of how to unhorse a man using grappling (fig. 7). The following explanatory text accompanies the treatise's last image:

"Once he has been forced out of the saddle or fallen, also get off of the horse and bind him quickly with wrestling techniques, enclosing him with one leg, the other (leg) on an arm, and work with a sword or dagger so that he gives himself up." 33

This laconic explanation is inscribed across the top third of the page. As is the case in many of the pages of Falkner's manuscript, the struggling figures extend into the lines of text, which break to accommodate a pommel raised aloft in a gauntleted hand. Such collisions of word and image suggest that the illustrations were drawn prior to the addition of Falkner's written instructions, and, in many cases, the pictures provide additional information that expands upon the didactic text. For instance, the illustration of the caption quoted above specifically depicts the aggressor aiming his blade through his victim's open visor and into his face, rather than simply "working with a sword." This strategy of targeting the visor-one of the primary week points in the steel carapace of plate armour - is explicitly described by Falkner elsewhere in the treatise, and his fighting style persists through this last image. ${ }^{34}$

The final image in Falkner's Art of Knightly Defense far surpasses the artistic quality of the other 140 images in the manuscript, and its artist is distinct from the other two draftsmen who illustrated the fight book. This artist's style and that of his less skilled collaborators, resembles contemporary Augsburg book illustrations. The graphic quality of the drawing, particularly the iconic representation of facial features such as eyes and noses, echoes styles

rediscovered Thun album. See Baptiste, "L'armure et ses typologies," 147. The Brotherhood of St. Mark, or Marxbrüder, were founded in Frankfurt, and, in 1487, Emperor Fredrick III invested them with the sole privilege of granting the title Master of the Longsword to teachers of the martial arts within the Empire. Lecküchner's Kunst des Messerfechtens influenced Falkner's work.

${ }^{33}$ Falkner, Kunst zu Ritterliche Were, circa 1491-1495 (KK 5012), fol. 72v; Tobler, Captain of the Guild, 316-317. "Ist er ab getrungen oder geffallen so fall aüch ab von dem pfertt vnd arbeit schnel in dem ringen als du wol weist felt er uff den rück so beschlüß in mit einen bein mit dem andern uff einen arm vnd arbeit mit der swert oder degen so ergypt er sich." While Tobler's transcription and translation of Falkner's treatise are excellent, his codicological overview of the book was impeded by the lack of direct analysis of the object. My thanks to Dr. Katja Schmitz von Ledebur for facilitating examination of the codex for this study.

${ }^{34}$ Falkner, Kunst zu Ritterliche Were, circa 1491-1495 (KK 5012). For instance, on folio 56r, in the section that details armoured fighting with daggers, and on folio $66 \mathrm{v}$, which demonstrates armoured combat with poleaxes. 
that developed among Augsburg Buchmaler, or book painters, in response to the demands of the woodcut printing industry. For instance, the fighters' large, expressive eyes with open inner corners and their small, triangular noses parallel features that appear in book illustrations produced during the last quarter of the fifteenth century and the first decade of the 1500s. This style, exemplified by single-leaf woodcuts and books published by Johannes Bämler and Anton Sorg, was developed by the cadre of Augsburg artists who were responsible for not only illuminating manuscripts, but also designing prints and handcoloring impressions. ${ }^{35}$ The first of the two artists who illustrated the Tournament Book and Family Chronicle of Marx Walther employed this style in his retrospective visualizations of tournaments held between 1477 and 1485. In an opening that depicts a Shrovetide joust between Walther and a fellow Augsburg patrician as tournament stewards dressed festively as fools cavort alongside the lists, representations of armour and facial features bear close resemblance to those in Falkner (fig. 9). ${ }^{36}$ The graphic, abbreviated treatment of eyes and noses as well as the simplified yet unambiguous depiction of particular types of armour connect both Walther's tournament book and Falkner's martial treatise to Augsburg book illustrations of the same period. Both works closely echo the style of the woodcut illustrations that accompany editions printed by Bämler and Sorg. ${ }^{37}$

In addition to the stylistic details that tie the Art of Knightly Defense to Augsburg, watermarks that appear on its pages suggest an origin in Swabia or Tirol, and perhaps in the imperial free city itself. The pinecone insignia of Augsburg — the Stadtpyr-marks two of the leaves in the manuscript's first and second quires, where it is surmounted by an imperial crown. In two more leaves in the codex's sixth and eighth quires, the Stadtpyr appears uncrowned..$^{38}$ Indeed, the last instance of this insignia emblazons the very page that echoes the drawing now in the Thun album. These watermarks were used widely in Augsburg during the 1480s and 1490s, especially in workshops associated with Bämler and the paper mill that he founded in 1486, and again from 1513 through the 1560s. ${ }^{39}$ These watermarks offer tangible evidence that reinforces the stylistic connections

\footnotetext{
35 Krause, Hans Holbein der Altere, 55-57; Susan Dackerman, Painted Prints, 22.

36 Marx Walther, Tournament Book and Family Chronicle (Cgm 1930), fol. 5v. Huber, Marx Walthers Turnierbuch, 38-39. Huber explains the scene and its Augsburg social context in more depth.

37 See, for instance, Johannes Hartlieb, The History of Alexander the Great, 1478 (Incun. 1478. L4), fols. 39r and $40 \mathrm{v}$.

38 Falkner, Kunst zu Ritterliche Were, circa 1491-1495 (KK 5012), fols. 6 \& 14 bear the crowned Stadtpyr, similar to Briquet Type 2111, while folios 55 and 72 bear the uncrowned Stadtpyr, similar to Briquet Type 2110. Briquet, Les filigranes, vol. 1, p. 156-7.

${ }_{39}$ Briquet, Les filigranes, vol. 1, p. 156. An additional watermark that appears in the third quire of Falkner's Fechtbuch also marks works created between 1485 and 1500 in Hallstatt and Rattenberg, thus corroborating the dating of Falkner's work and its association with the southern Holy Roman Empire.
} 
between the Art of Knightly Defense and the Augsburg contexts from which the Thun album and the drawings it collects emerged.

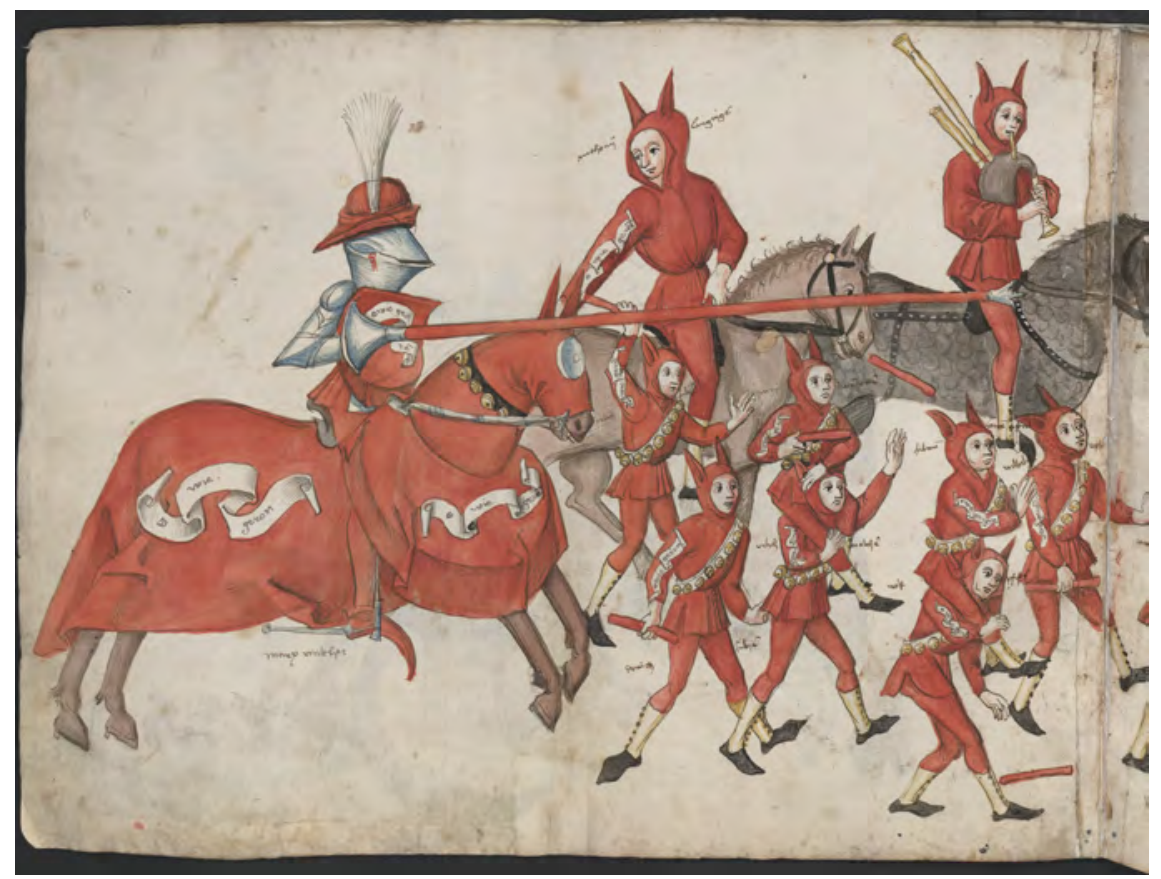

Fig. 9: Unknown Augsburg book painter, Shrovetide Joust between Marx Walther and Georg Hofmair with Parade of Stewards dressed as Fools, Tournament Book and Family Chronicle of Marx Walther, circa 1506-1511, Munich, Bayerische Staatsbibliothek, Cgm 1930, fol. $5 v$.

The Thun drawing differs markedly from its counterpart in the specificity and quality of its draftsmanship. The image of struggling figures offers a masterful representation of armour-encased bodies in motion. The artist modeled the sinuous, curved surfaces of the late-gothic style steel plates in cool shades of muted blue that echo the strategies for depicting armour established by Augsburg book painters. The image in the album is exceptional for its illusionistic detail. The links of mail that protect the victor's shoulders and peak out from beneath each figure's breastplate and arm defense are defined by minute lines or articulated in fine stippling. The linear repoussé that amplifies the form of nearly every steel plate has been sculpted in shades of steel blue, white, and grey wash. Unlike the loose, graphic style of the analogous illustration in the Vienna Falkner, the level of finish in this drawing from the Thun album approaches the accomplishment of a presentation drawing. Despite these stylistic differences, is conceivable that the drawing on folio $12 \mathrm{r}$ of the album, now trimmed along the outlines of its figures and landscape, was once part of a version of the text preserved in the manuscript of Falkner's Art of Knightly Defense. If it were indeed cut from a now-lost edition of this book, it must have been a remarkably fine copy. The analogies between the drawing on folio $12 \mathrm{r}$ and 
Falkner's treatise draws attention to compelling connections between the fight book genre and the Thun album drawings' origins in Augsburg, as well as its potential audience of viewers interested in martial culture.

\section{II.3. Martial Practice and Bellicose Knowledge in Word and Image}

Analysis of the textual and visual traditions of fight books and of martial compendia combined with an examination of their use by courtly and urban audiences offers an important avenue for understanding the Thun Album in its context. Considerations of readership trace the ways that martial knowledge was transmitted and, perhaps more importantly, commemorated through representations of the armoured body. Analysis of the genesis, circulation, and reception of fight books also reveals how such knowledge became a form of cultural capital. As such, it could facilitate social mobility by demonstrating indoctrination into chivalric society in exchanges between members of the urban elite, the knightly aristocracy, and the imperial court. ${ }^{40}$ These exchanges mirror those manifested the Thun album, whose contents and imagery also traverse the boundaries between aristocratic and urban socio-economic milieux.

Despite their rich pictorial content and relationship to both prose and verse texts, late medieval and early modern martial manuals have been overlooked in English-language art historical scholarship. ${ }^{41}$ Military historians or arms and armour specialists, such as Jeffrey Forgeng and Ken Mondschein, have published the few significant scholarly studies in English that focus on this genre of manuscripts. ${ }^{42}$ German and French scholarship is far more plentiful, and many works, such as the foundational contributions of Rainer Leng, Hans-Peter Hils, Rainer Welle, and Jan-Dirk Müller, focus on textual analysis or the interplay between image and text. ${ }^{43}$ However, dozens of fight books produced in the

${ }^{40}$ Hils, Meister Johann Liechtenauers Kunst des langen Schwertes, 212-215; Forgeng, “Owning the Art,”16465.

41 Anglo, The Martial Arts, 2-3. Over a decade ago, Anglo lamented the dearth of art historical scholarship on late medieval and renaissance martial manuals, which he surmised was a symptom of the discipline's avoidance of straightforward discussion of the details of personal violence. However, in the years since Anglo's publication, historians and art historians, including Carolyn Walker Bynum, Pia Cuneo, Valentin Groebner, and Mitchell Merback, have interrogated the role of violence and its representation in the creation and meaning of fifteenth- and sixteenth-century works of art. See, for instance, Walker Bynum, Christian Materiality; Cuneo, "Introduction," in Artful armies, beautiful battles; Groebner, Defaced; Merback, "Fount of Mercy, City of Blood."

42 See, for instance, Forgeng, The Medieval Art of Swordsmanship; Mondschein, The Knightly Art of Battle.

${ }^{43}$ Hils, Meister Johann Liechtenauers Kunst des langen Schwerts; Müller, "Zwischen mündlicher Anweisung und schriftlicher Sicherung von Tradition"; Leng, Ars belli. While each of these studies engages deeply with late medieval or renaissance martial manuals throughout their length, none approach the subject from an art-historical perspective, but rather seek to interpret the information contained 
Holy Roman Empire during the fifteenth and sixteenth centuries survive intact in European and American collections, awaiting art-historical analysis. ${ }^{44}$

Heidemarie Bodemer's ambitious dissertation offers one notable model for the analysis of images in late medieval and early modern martial manuals. Bodemer analyzes a cross section of the most well-known illustrated treatises produced in the Holy Roman Empire from the thirteenth through the eighteenth centuries, ranging from foundational works by fifteenth-century fencing masters such as Hans Talhoffer and Paulus Kal to artistically innovative manuscripts by artists like Albrecht Dürer and Gregor Erhart. ${ }^{45}$ However, the author concedes that the quantity of surviving volumes and fragments of martial manuals, as well as their tendency to be bound into collected anthologies of disparate material scattered among libraries throughout Europe and the United States, has prohibited a comprehensive study of the genre. ${ }^{46}$ Daniel Jaquet's growing body of scholarship on individual fight books, as well as the modes of communication deployed within the genre and the patterns of exchange that link particular volumes and fighting schools to one another, establishes important pathways to understanding this idiosyncratic genre. ${ }^{47}$

Fight books gave concrete form to an oral tradition that relied on knowledge transmitted directly from master to student and reinforced through rigorous physical practice. Their development represents the translation of primarily oral and performative martial practice into image and text, and the memorable verses and illustrations that characterized the genre participated in the broader cultural phenomenon of didactic poetry. While poets writing mirrors for knights or princes often incorporated the same classical sources of military knowledge employed by fencing masters, they used vividly descriptive language

in the manuscripts and how its was conveyed through text. For a signicant exception, see Welle, “...und mit der rechten faust ein mordstuck,", especially 108-131.

44 Bodemer, "Das Fechtbuch," 16-20. Due to the scattered, and often fragmentary, state of extant martial manuals, Bodemer analyzes a representative group of complete manuscripts that were readily accessible in European public collections as case studies that demonstrate the patterns of development which shaped the genre.

45 Bodemer, "Das Fechtbuch," 3-4. Bodemer's exceptional dissertation has forged important inroads into the art-historical analysis of the German martial manual tradition. Her work will, hopefully, provide a point of departure for more focused analyses, including future studies in English that will address this vast lacuna in the English-language history of late medieval and Northern Renaissance art.

46 Bodemer, "Das Fechtbuch," 14. Bodemer surmises that over 300 complete martial manuals or fragments survive from the late medieval and early modern periods. Beyond her approach involving significant case studies, one potential means of dealing with this daunting body of work could be found in a prosopographic approach that would treat each surviving example as a data point in order to identify larger patterns of the transmission, patronage, reception, and afterlives of martial manuals. See Verboven, Carlier, and Dumolyn, "A Short Manual to the Art of Prosopography," 4546, 48-49.

${ }^{47}$ See, for instance, Jaquet, "Introduction,"and "Die Kunst des Fechtens in den Fechtschul." 
and their poems were only sometimes illustrated. ${ }^{48}$ Conversely, fight books could contain much more succinct, even sparse text, and often relied heavily on images to convey the author's meaning. ${ }^{49}$ The close association between image and text in fight books was so memorable that it would likely have inflected the reception of related images, including those that were re-contextualized as part of the Thun album.

Fight books initially focused primarily on skills deployed in single combat with swords without the protection of armour. ${ }^{50}$ Such treatises emphasized techniques for fighting with German two-handed swords or a combination of the so-called hand-and-a-half (or bastard) sword and a buckler. Often, these works presented themselves as defensive manuals for civilians concerned about violence in the medieval city or while travelling, or as textbooks for preparation for duels or trials by combat. ${ }^{51}$ However, the didactic value of these volumes for readers not already indoctrinated through physical training is suspect, since it would be difficult to accurately reconstruct complete repertoires of combat from even the most elaborate manuscript source. Therefore, fight books must be analyzed as mnemonic works that recalled and celebrated knowledge, aspirational works that embodied chivalric prowess that their owners claimed or wished to acquire, or demonstrative works that advertised their authors' expertise, as well as manuals on how to fight.

Fechtschule des Meister Johann Liechtenauer established the lineage of vernacular martial manuals in the German-speaking lands. Assembled from collected notes set down by a single writer over several years around 1389, this work became more commonly known as the Kunst des langen schwerts, or The Art of the Long Sword. ${ }^{52}$ As Bodemer observes, Liechtenauer was the first Fechtmeister to emerge from anonymity, but his contribution was built upon a synthesis of fighting strategies and teaching techniques that had developed

48 The late-Roman military strategist, Vegetius, was a popular source cited in both didactic poems directed to the aristocratic and knightly elite, and the martial manual genre. See, for instance, Johannes Rothe, "Der Ritterspiegel," 189-195. One notable example of illustrated Lehrgedicht, or didactic poetry, is a late fifteenth-century version of Hugo von Trimburg's Der Renner, originally written during the early-fourteenth century. Hugo von Trimburg, Der Renner, last quarter of the fifteenth century, (M.763).

49 Welle, “...und mit der rechten faust ein mordstuck,", 108-110, 114-118

50 The earliest extant example of such a treatise is the so-called Walpurgis Codex (MS I.33), written in Latin and named after a woman who is represented among the fencers on its pages. See Forgeng, The Medieval Art of Swordsmanship.

${ }^{51}$ Hils, Meister Johannes Liechtenauers Kunst, 209-213; Groebner, Defaced, 40-52. Groebner's analytical social history of violence in late medieval Europe presents valuable case studies on the nature of urban conflicts between powerful interest within the cities of the southern Holy Roman Empire and the Swiss Confederation. See also Anglo, The Martial Arts, 7-11. On pages 8 and 9, Anglo points out the perceived threat embodied by martial artists and the subsequent bans on instruction or establishment of fencing schools throughout fourteenth-century Europe.

52 Burkart, “The Autograph of an Erudite Martial Artist," 261-265.

Acta Periodica Duellatorum 6(1), 2018 
slowly over the course of the fourteenth century. ${ }^{33}$ Although the treatise attributed to Liechtenauer contains only short, cryptic verses intended to accompany physical training, his teachings became the authority to which nearly all subsequent German-language fight books refer as a source. ${ }^{54}$ Well into the sixteenth century, fencing masters who committed their wisdom to the page almost invariably cited Liechtenauer. For example, Paulus Kal's dedication of his fight book to Duke Ludwig of Bavaria-Landshut in 1479 stated: "Here I give to you the art that Liechtenauer, along with his community, made and passed down to all who are knightly by the grace of God." ${ }^{55}$

As fight books proliferated, their curriculum expanded beyond unarmoured swordfighting. ${ }^{56}$ Beginning in the second quarter of the fifteenth-century, fencing books often included combat on foot in full armour with swords and hafted weapons; mounted combat with and without armour using a variety of weapons; wrestling or grappling; and judicial duels between combatants of the same gender or between men and women. This range of martial combat demonstrates the appeal of fight books across broad swaths of the socio-economic spectrum. The pupils of fencing masters and the audiences for martial arts treatises included university students, burghers, clergy (particularly collegiate priests, such as canons), knights, noblemen, princes and emperors. Documented owners of martial manuals included craftsman, such as the hat-maker and fencing master in his own right, Jörg Wilhalm, civic official Paulus Hector Mair, and Emperor Maximilian I, whose library at Schloss Ambras included treatises from both the German and Italian military traditions. ${ }^{57}$ Extant fifteenth- and sixteenth-century fight books include low-quality books

53 Müller, "Zwischen mündlicher Anweisung und schriftlicher Sicherung von Tradition," 381; Anglo, The Martial Arts, 12, 45-46. Bodemer, "Das Fechtbuch," 102-103; Fechtschule des Johannes Liechtenauers (also known as Kunst des Langen Schwerts), 1389 (Germanisches National Museum inv. 3227a).

54 Müller, "Zwischen mündlicher Anweisung und schriftlicher Sicherung von Tradition,” 381-382; Anglo, The Martial Arts, 40-46. Bodemer, "Das Fechtbuch," 74-75.

55 Bodemer, "Das Fechtbuch," 124; Paulus Kal, Fechtbuch dedicated to Pfalzgraf Ludwig, before 1479 (Cgm 1507), fol. 2r. "hye gebt a ire kunst die liechtenawer mit seiner geselschafft gemacht und gepraucht hat in aller ritterlicher wer das im got genädig sey."

56 The practice of sword-fighting without the protection of armour was commonly called Bloßfechten, or bare fighting. Bloßfechten, like grappling (Ringen) was considered a foundational aspect of martial training, and students were expected to master it prior to learning how to fight in armour or against armoured foes.

${ }^{57}$ Jörg Wilhalm "Hütter," drafted three versions of his own fencing manual between 1520 and 1523 (Cod. I.6.2.2, Cod. I.6.2.3, and Cod. I.6.4.5), and the book's parallels to the works of Kal and Falkner seem to indicate the author's familiarity with or ownership of those masters' works. Hütter's works were later purchased by Paulus Hector Mair. The library at Schloss Ambras, which was founded upon works collected by Maximilian I at Innsbruck, included a martial compendium (Cod. 5278) that contained Konrad Keyser's Bellifortis and Der Blume des Kampfes, a German translation of the North Italian Fiore dei Liberi's Fior di Battaglia, as well as one of the oldest surviving Germanlanguage fight books. The emperor also owned an anonymous manuscript from the Gladiatoria Acta Periodica Duellatorum 6(1), 2018 
with crude or absent illustrations, as well as manuscripts that were richly illuminated by illustrious workshops with illustrations highlighted in metallic leaf or vivid dedicatory miniatures. ${ }^{58}$ Among the surviving examples are drafts and personal copies of influential fencing masters, such as Hans Talhoffer and Jörg Wilhalm, as well as fragments or excerpts of treatises that, like the drawings in the Thun album, have been incorporated into collected anthologies, or compendia, whose contents span disciplines ranging from alchemy, chemistry, and pyrotechnics to commemorative histories of tournaments to astrology and even magic.

\section{II.4. Pictorial and Literary Mnemonic Strategies in Martial Treatises}

Late-medieval and renaissance masters of arms used fight books to establish the usefulness of their discipline. These volumes employed rhetorical strategies purported to help readers commit their wisdom to memory, and that aided in the recollection of martial knowledge. The impact of these rhetorical forms was amplified by the illustrations that populated martial treatises, which prompted viewers to envision themselves performing the techniques promoted by fencing masters.

As the fight book genre gained momentum, the verses, or zedel, passed down through the Liechtenauer tradition were glossed with prose explanations to facilitate their function as instructive texts, as well as auxiliary mnemonic prompts. For example, surviving versions of a treatise written in around 1430, known as "Gladiotoria," after an inscription in the beginning of one of the manuscripts, include expanded descriptions of numbered movements based on Liechtenauer's system..$^{59}$ These codices juxtapose straightforward verbal instructions for where to place feet, hands, and sword to accomplish particular maneuvers with elegant, demonstrative illustrations. Folio $11 \mathrm{v}$ of the earlier manuscript, KK 5013, narrates the motions visualized in figure 10, which represents the second of two maneuvers known as the "Way of the Joints":

Note the second part pf the way of the joints. When both thrust at each other with all of their strength and you want to execute this strike against him, then thrust at him yet again from the outside of his sword with the point towards him, bring the pommel over the outside of his left arm and pull strongly towards yourself. Thus, you will break his arm and throw him, as you see it painted above. ${ }^{60}$

group (KK 5013). Thomas and Gamber, Katalog der Leibrüstkammer, vol. 1, 66; Bodemer, "Das Fechtbuch,” 121-123.

58 Bodemer, "Das Fechtbuch,” 109-110,

59 Thomas and Gamber, Katalog der Leibrïstkammer, 66; Hagedorn and Walczak, Gladiatoria, 60; Bodemer, "Das Fechtbuch," 119-121.

${ }^{60}$ Hagedorn and Walczak, Gladiatoria, 226. In the edited and glossed facsimile of the New Haven version of the Gladiatoria (formerly in Gotha), Hagedorn and Walczak transcribe the Vienna 


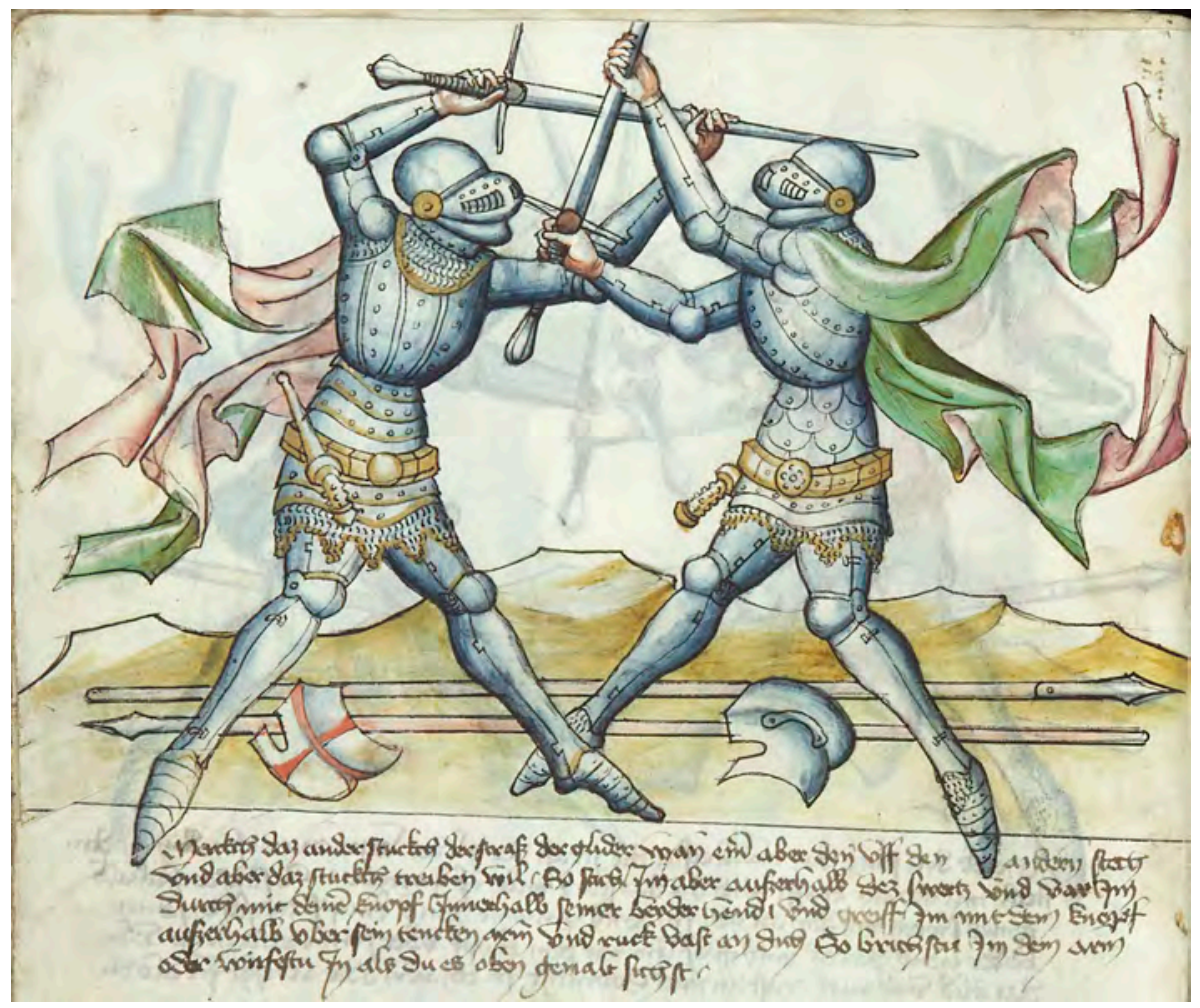

Fig. 10: The "Way of the Joints," Gladiatoria, circa 1430, Vienna, Kunsthistorisches Museum, KK 5013, fol. $11 \mathrm{v}$.

That last phrase, "as you see it painted above," is a refrain, repeated on nearly every page throughout the Gladiatoria codices. Importantly, these manuscripts not only demonstrate textual expansion of the zedel, but also the increasing emphasis on images of combatants, which were once illustrative accompaniments to the Fechtmeisters' verses, as important sites of knowledge that participated in dialogue with the text and expanded upon the meanings that it conveyed to the reader/viewer. ${ }^{61}$

manuscript passage on this maneuver to stand-in for the lost text portion of folio $7 \mathrm{v}$ of the New Haven version. The fifteenth century German script in KK 5013, fol. 11v reads: "Merck daz ander stuck der straß der glider wann ein aber den auf den andern stech/und aber daz stuckh treiben wil, so stich im aber außerhalb der swertz und da im/ durch mit deine knopf innerhalb seiner beyder hände, und greiff im mit dem knopf/ außerhalb uber sein linken arm und vast an dich So brikst Im den arm oder wirfest In als du es oben gemalet siechst.“

${ }^{61}$ Müller, "Zwischen mündlicher Anweisung und schriftlicher Sicherung von Tradition,” 382-83. Welle, “...und mit der rechten faust ein mordstuck," 108-109. 
Fight book imagery built upon themes of teacher-student dialogue that characterized the genre's verses and prose, as well as its origins in the personal exchanges of the fencing school. ${ }^{62}$ Depictions of particular maneuvers or stances visualized the teacher who, although absent in body, could prompt recollection of physical knowledge through his pictorial presence. Hans Talhoffer's fighting manual, which first appeared in 1443 and appeared in numerous iterations over subsequent decades, offers a vivid example of the fight book as a surrogate for the fencing master. The version of his treatise created in 1459, which has been interpreted as his personal copy, declares, "This book is Master Hans Talhoffer's and he has himself modeled with his maneuvers so that the book has been painted after him." ${ }^{3} 3$ This inscription defines the images that surround it as proxies for Talhoffer's own expert presence, which illustrations that visualize the master himself tangibly evoke (fig. 11). ${ }^{64}$ The textual testament to the fighting manual as a surrogate for the master's personal instruction finds a visual complement in the dedicatory miniature of Paulus Kal's Fechtbuch for Ludwig of Bavaria-Landshut, which depicts the master, clothed lightly as if for fencing practice, presenting his armoured patron with a sword (fig. 12). The Madonna, Christ Child, and Saint George bear witness from a floating cloud as Kal declares, "Take this sword, gracious lord, and you will be protected by the Mother of God and the Knight of all Knights, Saint George."65

${ }^{62}$ Krause and Kaindel, "Das Große Kartenspiel," 7.

${ }^{63}$ Talhoffer, Fechtbuch, 1459 (MS Thott.290.2o), 103v. "Item daz buch ist maister Hansen Talhoffers und der ist selber gestanden mit sinem lybe bis daz man daz buch nach im gemalet hat, und das ist gemalet worden off pfingsten." The entire inscription suggests the the illustrations were drawn during one day of demonstrative modeling, an unlikely claim given the quality of the images.

${ }^{64} \mathrm{It}$ is interesting to note that Talhofer wears a badge with the winged lion of the Marxbrüder in the portrait that appears on fol. 101v of the Copenhagen manuscript.

${ }^{65} \mathrm{Kal}$, "Fechtbuch dedicated to Pfalzgraf Ludwig," circa 1470 (Cgm 1506), 5r. "Nemt hin genediger Herr das schwert ir wert von der muter gots und riter sand iorgñ aller riterschafft gewert." 

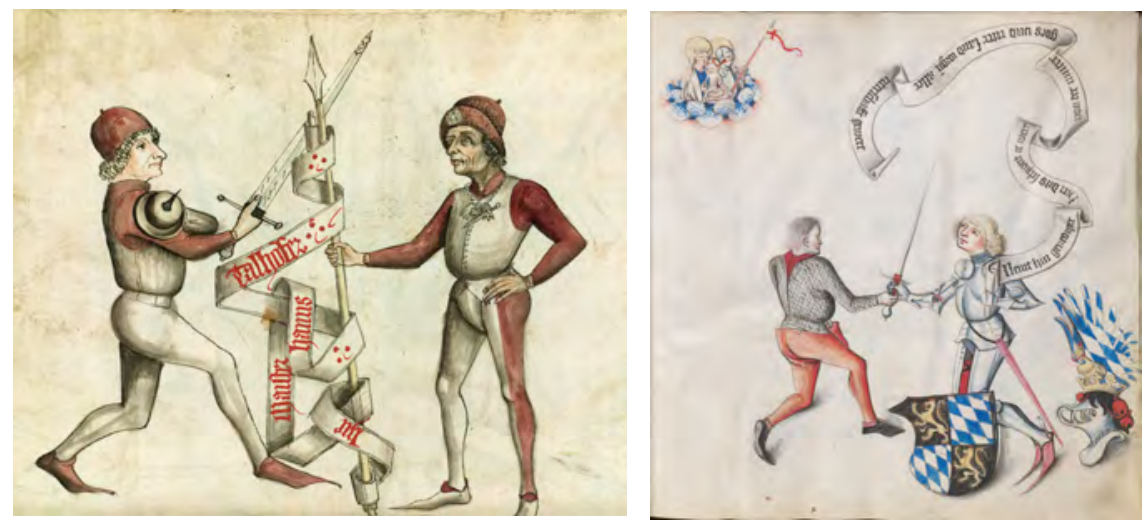

Fig. 11 (left): Hans Talhofer, wearing the badge of the Marxbrüder, and a student, 1459, Copenhagen, Det Kongelige Bibliotek, MS Thott.290.2o, fol. $101 \mathrm{v}$.

Fig. 12: Dedicatory Miniature, Paulus Kal's Fechtbuch for Ludwig of Bavaria, Bayerische Staatsbibliothek, Cgm. 1507, fol. 5 r.

As fight books relied increasingly on pictorial communication, the indoctrinated viewer would have been called upon to "textualize" the minimally captioned or completely unannotated images. Like the laconic verses so often deployed in the genre, the illustrations of martial manuals functioned as mnemonic prompts that could induce viewers to recall not only the verbal rhymes associated with them, but entire repertoires of movement and strategy. Thus, the glimpses of armoured and unarmoured combat that appear in the Thun album's fifteenth-century drawings could have stimulated viewers' recollection of the actions that constituted particular fighting traditions, the verses that helped commit them to memory, and the absent masters who taught them.

To demonstrate this possibility, Paulus Kal's fight book made in 1479 for Ludwig of Bavaria-Landshut exemplifies the primacy of images over texts typical of many late fifteenth-century martial manuals. ${ }^{66}$ The manuscript is sumptuously illustrated, and the sensitivity with which the book painter rendered contemporary armour has led some scholars to compare its images with the fifteenth-century drawings in the Thun album. ${ }^{67}$ An illustration in the book's first section, which contains instructions for mounted combat, represents two figures striking either underhand or overhand blows (fig. 13). The movements are labeled curtly as "The Third Strike," and "The Fourth Strike," presumably in reference to the system of numbered strokes used by Leichtenauer and his successors

66 Hans Lecküchner, Kunst des Messerfechtens, 1478 (MS. Cod. Pal. Germ. 430). The version of Lecküchener's Kunst des Messerfechtens, now in Heidelberg, is an important exception to the trend.

${ }^{67}$ Bodemer, "Das Fechtbuch," 130-131. Based on Gamber's research on the then-lost Thun album, which he concluded contained models or patterns for artists or armourers associated with the Helmschmids, Bodemer connected the style of the Kal Fechtbuch to the fifteenth-century Thun drawings. 
to introduce the basics of swordplay. In contrast to the page's minimal text, the two figures and their steeds are fully visualized, and do indeed bear striking parallels to the mounted pairs who spar in the opening of the Thun album. The figure on the left sweeps his sword toward his opponent in the underhanded "Third Stroke", his upturned wrist exposing the red lining of his armoured gauntlet; the right-hand figure, whose war hat and dappled mount recall his counterpart in the Thun album, deflects his opponent's blow with a firm, over-handed strike. While the text barely alludes to these skillful movements, the images dramatically enact them on the page, and prompt the viewer to do so in his mind.

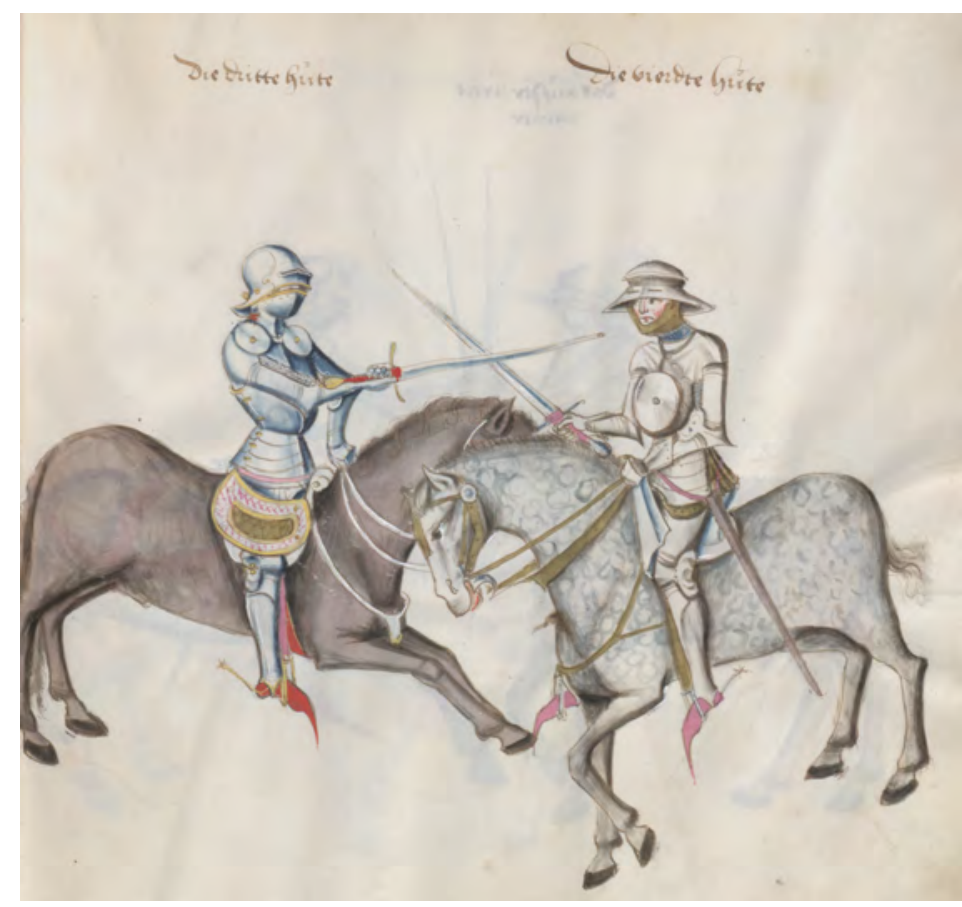

Fig. 13: The Third and Fourth Strikes, Paulus Kal's Fechtbuch for Ludwig of Bavaria, Bayerische Staatsbibliothek, Cgm. 1507, fol. 13 r

\section{CONTEXTUALIZING THE THUN ALBUM'S ARTISTIC CULTURE \& CODICOLOGY}

\section{III.1. "Ritterliche Kunst": Transmission and Innovation in Augsburg Martial Manual Imagery}

The fight book tradition that encompassed the works of Talhoffer, Kal, and Falkner, and which transmitted their influence, was deeply familiar to the Augsburg artistic circles that 
produced the 106 mid-sixteenth century drawings that fill most of the Thun album. Examination of martial manuals and related works that were produced during the first half of the 1500s reveals how fight books shaped the ways that Augsburg artists envisioned the armoured body. Furthermore, such consideration suggests the ways that the genre's reliance on depictions of armoured figures inflected viewers' engagement with the drawings that the album contains, encouraging them to see the drawings as sites of meaning and memory.

The collections and publications of Paulus Hector Mair, a city councilman, author, collector and ill-fated fencing enthusiast, demonstrate the popularity of martial manuals in sixteenth century Augsburg. Inventories of Mair's property were compiled during the liquidation of his possessions following his execution in 1579. These documents describe a range of artworks, texts, and weapons that intersect conceptually with the drawings that comprise the Thun album. ${ }^{68}$ At the time of his death, Mair possessed around twenty-five books related to chivalry, tournaments, and martial knowledge; this number is imprecise because the inventory ceases to count the numerous "gefangennen Fechtbücher," or collected fight books, that included seven works now held at the Universitätsbibliothek Augsburg. ${ }^{69}$

Fourteen fight books and martial compendia that Mair collected or commissioned survive. ${ }^{70}$ These codices have often been rearranged and rebound to combine fifteenthcentury works by fencing masters working in the tradition of Liechtenauer with related, sixteenth-century treatises by the Augsburg hatter Jörg Wilhalm. One example among Mair's Sammelbände, or collected volumes, includes the ordinances and history of the Marxbrüder, the martial guild to which Talhoffer belonged and which Peter Falkner led from 1502 until $1506 .{ }^{71}$ Indeed, the insignia of the Marxbrüder appears in Talhoffer's treatise from 1459 and it was pasted onto a blank folio in Falkner's Kunst ₹u Ritterliche Were. Two codices from the 1520s that are attributed to Jörg Wilhalm—-the first of which is a nearly atextual draft copy of the drawings that are accompanied by fuller text in the more complete second manuscript-visualize figures whose armour, costumes, and

${ }^{68}$ Confession, Court Records, Inventories, and Sales-Records of Paulus Hector Mair, November 1579-May 1580 (Augsburg, Stadtarchiv, Urgichten K262, 1579-80).

69 An additional compilation of fighting treatises held in Augsburg (Codex I.6.4 .3) may have belonged to Mair, but it lacks the tangible evidence, including inscriptions in Mair's hand, that appears in other codices from his collection. For more on Mair's work as a collector, author, and martial enthusiast, see Mauer, "Sammeln und Lesen - Drucken und Schreiben," 107-132, Kusudo, “P.H. Mair (1515-1579)," 337-354, and Forgeng, "The Martial Arts Treatise," 267-283.

70 Martial treatises and compendia that are associated with Mair include Augsburg Universitätsbibliothelk Cod. I.6.2.1, Cod. I.6.2.3, Cod. I.6.2.5, Cod. I.6.2.2, Cod. I.6.4.1, Cod. I.6.4.5, and Cod. I.6.2.4; in Vienna: Mair, De Arte Atbletica, 1545-1555 (Cod. 10825 and 10826); in Munich: Mair, De Arte Atbletica, 1545-1555; in Dresden: Mair, De Arte Atbletica (MSS Dresden C 93 and C 94).

71 Mair (compiler), Augsburger Fechtordnung, Frankfurter Fechtbruderschaft, Johannes Liechtenauer: Kunst des langen Schwerts, circa 1540s (Cod. I.6.2.5), fols. 9v-10v. 
gestures closely emulate the early fifteenth-century images that illustrate the Gladiatoria group of fight books (fig. 14). ${ }^{72}$ These works not only attest to the pathways by which fifteenth-century martial treatises and their images were collected and compiled in sixteenth-century Augsburg. They also reveal how sixteenth-century authors and artists consciously emulated their visual and rhetorical styles, creating early modern images that displayed strikingly anachronistic representations of the late-medieval armoured body. Perhaps most tantalizingly for the study of the Thun album, sixteenth-century fight books and their fifteenth-century antecedents directly influenced the modes of representing arms and armour that appear in the album, while also demonstrating how even depictions of armoured bodies unaccompanied by text could prompt remembrance of martial practices.
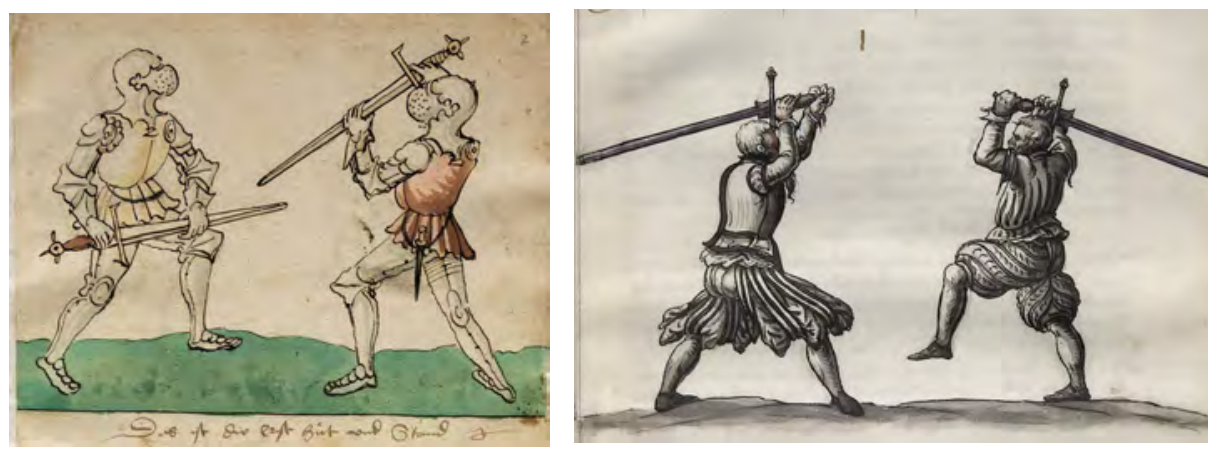

Fig. 14 (left): The First Strike, Jörg Wilhalm, Fechtbuch, circa 1522, Universitätsbibliothek Augsburg, Cod. 1.6.2.3. fol. $2 r$.

Fig. 15: Jörg Breu the Younger, Overhanded Strikes, Sammelband (Augsburger Fechtordnung, Frankfurter Fechtbruderschaft, Johannes Liechtenauer: Kunst des langen Schwerts), Universitätsbibliothek Augsburg, Cod. I.6.2.5, fol. $23 r$.

Eight of the martial works that Mair organized and commissioned were illustrated during the 1540s by Jörg Breu the Younger or during the 1550s by members of his workshop, shortly after the master's death in $1547 .{ }^{73}$ Rough illustrations that Breu created for a fencing treatise that Mair bound alongside the ordinances of the Marxbrüder and for another diverse compilation of martial knowledge from around the same period (fig. 15) demonstrate how the artist and his workshop incorporated the visual strategies employed by earlier fight books. The second of these examples, known simply as a Ring- und

${ }^{72}$ Jörg Wilhalm, Draft Fechtbuch, circa 1520 (Cod. I.6.4.5) and Jörg Wilhalm, Fechtbuch, circa 1522 (Cod. I.6.2.3)

73 These include three versions of the two-volume opus, De Arte Atbletica, Cod. 10825/26; Cod. icon 393a-b; Ms. Dresden C 93 and C 94; Cods. I.5.2.5, I.6.2.2, I.6.2.4. Mair also commissioned the Geschlechterbuch der Stadt Augsburg (Cod. icon 312b), a hand-colored, printed volume, from the Breu workshop and he may have owned at least two copies of Ritterspiele von Friedrich III und Max in den Jahren 1489-1511 (Cod. icon. 398 and Cod. I.6.4.1). 
Fechtbuch, not only includes Breu's characteristic images of fencers and grapplers clad in elaborately puffed and slashed sixteenth-century fashions. It also contains mid-sixteenth century illustrations that adopt the style of the fourteenth century; in doing so, these images acknowledge the perceived authority of late medieval martial traditions. Folios 14 and 15 depict combat with sword and buckler (fig. 16). Although illustrated by Jörg Breu the Younger during the 1540s, their content and style evoke far older works, such as the so-called Walpurgis Manuscript, Royal Armouries I.33.74 The costume and facial physiognomies of Breu's figures echo those in this rare early fencing treatise, and suggest that Breu may have had access to a manual of similar date from Mair's or another Augsburg collection.

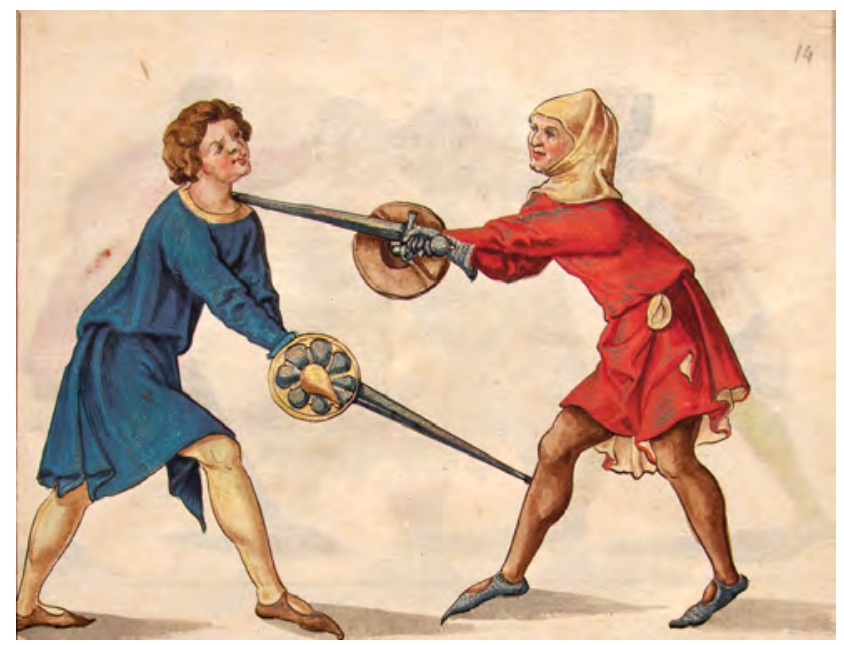

Fig. 16: Jörg Breu the Younger, Sword and Buckler, Paulus Hector Mair, Sammelband (Ring- und Fechtbuch), Universitätsbibliothek, Augsburg, Cod. I.6.2.4, fol. 14r.

In addition to the sketches and illustrations that Breu contributed to Mair's bound collections, the artist and his workshop also devised innovative strategies for representing armoured bodies and the arms they wielded. Mair's expansive treatise on the histories and strategies of combat for the battlefield, tournament, and duel, the Opus Amplissimum de Arte Athletica exists in four iterations in German and Latin. Two of these versions, now in Munich and Vienna, each comprise two volumes and over 600 folios. Mair sold the earlier of these versions of De Arte Atbletica, which presents the German vernacular fight book tradition entirely in Latin, to Duke Ludwig of Bavaria in 1567 for the substantial

\footnotetext{
74 Paulus Hector Mair and Jörg Breu the Younger, Sammelband, circa 1540s (Cod. I.6.4.2), fols. 14 and 15; Walpurgis Fechtbuch, circa 1420s (MS I. 33), fol. 23v; Kirchhoff, "Armors' Afterlives." While this interpretation arose independently based on first-hand analysis of the manuscript in Augsburg, Jeffrey Forgeng's research, published in 2003 and 2017 both predates and firmly corroborates this point. See Forgeng, "The Medieval Art of Swordsmanship," 12-13, and "The Martial Arts Treatise," 281-283.
} 
sum of 800 Gulden. ${ }^{75}$ This work, almost entirely illustrated by Breu the Younger himself, uses layers of metallic washes to evoke the iridescent surfaces of blued steel armour and weapons. The sections on mounted combat in armour, in particular, use veils of metallic wash to vividly approximate the plate armour for which Augsburg was famous (fig. 17). Their shimmering, closely observed visualizations of the armoured body parallel the roughly contemporary sixteenth-century drawings that the Thun album collects. However, Breu the Younger's heavy layers of opaque pigments beneath the metallic washes differ markedly from the translucent application of pigments employed by both of the artists whose works comprise 101 of the album's 112 images.

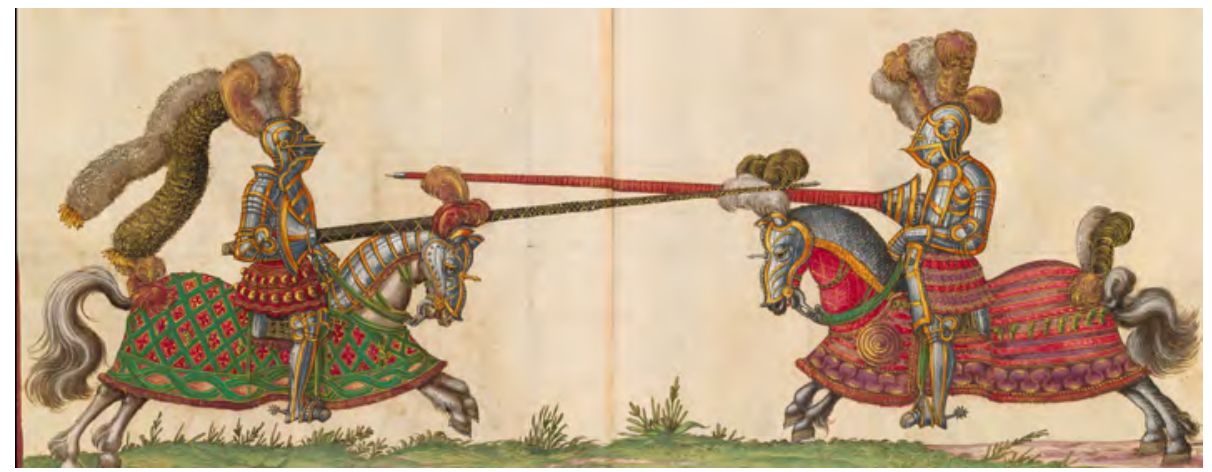

Fig. 17: Jörg Breu the Younger, The Joust of War in Armets, from Paulus Hector Mair, De Arte Athletica, Bayerisches Staatsbibliothek, Cod. icon. 393.b, folios 106v-107r

The Vienna version of Opus Amplissimum de Arte Athletica was likely created around or just after 1547, and it juxtaposes Latin and Early New High German translations of the Germanic fight book and tournament book traditions, along with purported transcriptions of earlier sources on the tournament that date to the Carolingian and Ottonian eras. ${ }^{76}$ This two-volume work incorporates illustrations by several now-

\footnotetext{
75 Mair, De Arte Athletica, (Cod. icon. 393a-b). This two-volume, 622-page work exclusively comprises paper marked with a Latin K (Briquet type 8257 or 8258) used in Swabia from the mid1530s through the mid-1540s. This predates the period of use for the papers that occur in the Vienna version of De Arte Atbletica (Briquet type 145), which were used predominantly during the late 1540s (especially 1546-47). C. M. Briquet, Les filigranes, vol. 1, 27 and vol. 3, 466. The manuscripts passed directly from the Bavarian ducal library into the Bayerisches Staatsbibliothek.

${ }^{76}$ Mair, De Arte Athletica, circa 1545-1555 (Cod. 10825), fol. 4v, for instance, describes tournaments in the reign of Henry the Fowler (876-936) (Henricus primus, eue nobis Romanora Imperator, ei eutiderat gloria Germanora); Mair, De Arte Athletica, circa 1545-1555 (Cod. 10826), fols. 157r-173v Acta Periodica Duellatorum 6(1), 2018 
anonymous book painters of the Breu workshop, each of whom also made vivid use of metallic washes to sculpt the armours, weapons, and costumes that he depicted. Images by artists who illustrated the sections on armoured combat on foot that populate the last sections of the second volume bear particularly tantalizing similarities to the sixteenthcentury drawings that fill the Thun album (fig. 18). These works, like the sixteenth-century drawings by the anonymous Artist A that the album collects, build the forms of armoured bodies from confidently loose lines that are drawn in black ink, which provide armatures for layers of translucent gouache, highlighted with veils of metallic wash.

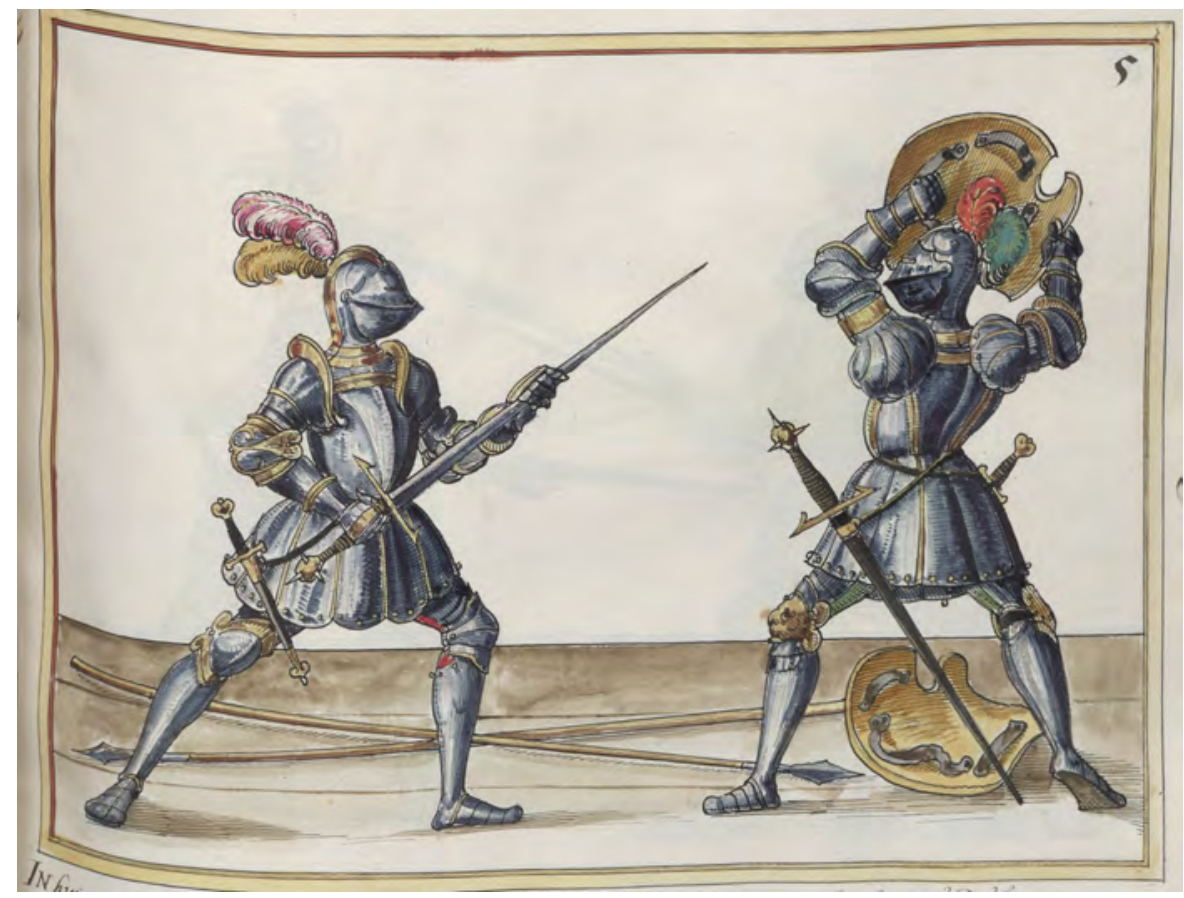

Fig. 18: Workshop of Jörg Breu the Younger, De Arte Athletica vol. II, circa 1542, Vienna, Österreichisches Nationalbibliothek, Cod. 10826 Han, fol. 208 r.

Comparative analysis of fight books created from the mid-fifteenth through midsixteenth centuries reveals compositional and stylistic relationships that tangibly tie the Thun album's contents to the fight book genre, and to the fifteenth-century drawings in the interlude between the first and second quires (see figs. 1 and 2). The album's echoes of fight books that were produced in the German speaking lands, resonate even more strongly with fight books that emerged from the city of Augsburg. The artistic lineagesfrom the printshops of Sorg and Bämler to the Breu workshops- that contributed to the

contain descriptions of tournaments held between the ninth and fifteenth-centuries, culminating with the well-documented Tournament of the Four Lands. 
character of Augsburg martial manuals like the Art of Knightly Defense and De Arte Athletica, suggest the connections that period viewers may have made between the album's fifteenth-century interlude and the sixteenth-century drawings in the quires that surround it.

\section{III.2. Incorporated Antecedents: Visions of Martial Knowledge within the Album's Codicology}

To modern viewers, the two drawings that derive from the fight book tradition (see figs. 1-2) may seem isolated from the Thun album's sixteenth-century contents by their insertion as a distinct unit separated from the first quire by the blank page that has been glued onto the recto of folio 10 , before the fifteenth-century opening. This expanse of blank paper creates a visual pause between the last figure of the first quire, who is clad in armour that dates to the period between 1515 and 1520 (fig. 20), and the older drawings that follow. Indeed, this figure's equipment-field armour fitted with reinforcing pieces for a grueling type of melée-style tournament that emulated the chaos of the battlefieldseems to anticipate the bellicosity of fifteenth-century images just beyond the blank facing page. This connection suggests how the fifteenth-century drawings were carefully placed adjacent to images that intersect with their themes.

The three folios that support the fifteenth-century drawings cling to a single, short tip of early-seventeenth-century paper that is contiguous with the tips used to anchor the drawings in the album's second quire (fig. 19). Thus, folio 12, whose recto forms the surface to which the fragmentary drawing of fifteenth-century swordsmen is pasted, constitutes both the last of the inserted drawings and the first leaf of quire two.

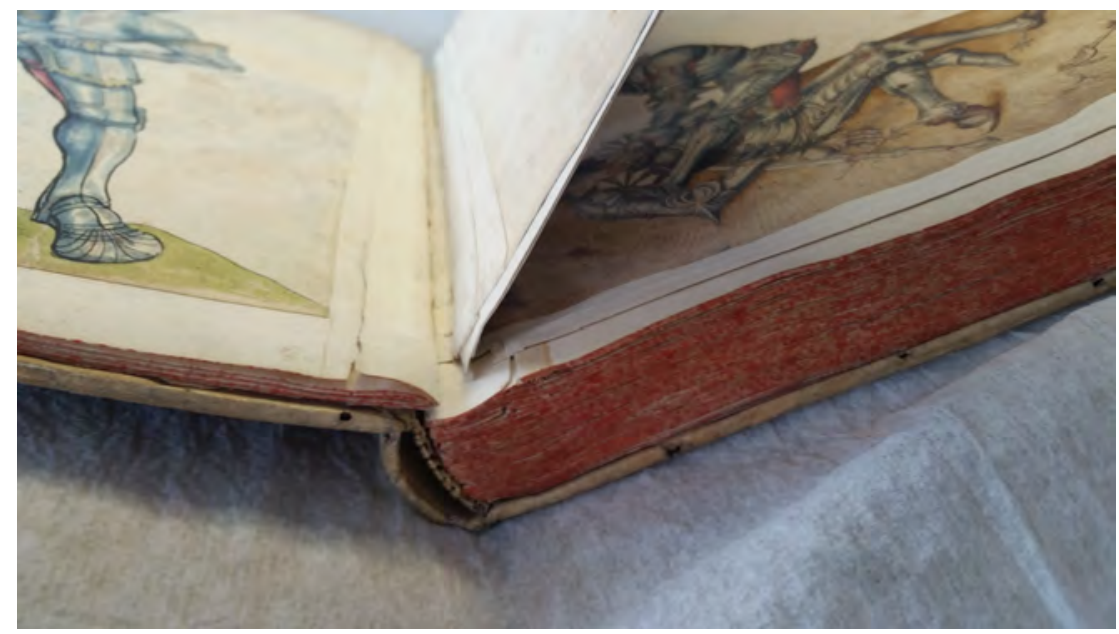

Fig. 19: View of the interlude of pages between the album's first and second quires, all glued onto the same short tip that forms folio 12, Thun-Hohenstein Album, Prague,

Umèleckoprimyslové museum v Praze, GK 11.572-B, folio 10-12. 
The paper of folio 12 dates to the 1540s and its verso bears a drawing by Artist A that retrospectively portrays a combatant in the tournament on foot, or Fußkampf, equipped in the style of the late-fifteenth century (fig. 21). He wears archaic mail chausses, or hose, along with a sallet in the style of the $1480 \mathrm{~s}^{77}$ This figure grasps a poleaxe, a particular type of staff weapon wielded primarily by armoured members of the knightly classes. In his right hand, he holds a rondel dagger, whose disc-shaped pommel and diamond-shaped blade were designed for use against armoured opponents. The version of armoured combat on foot that this figure embodies suggests parallels with the fighters whose silhouettes are glued onto the page's recto, which the album's compiler and viewer may have perceived.
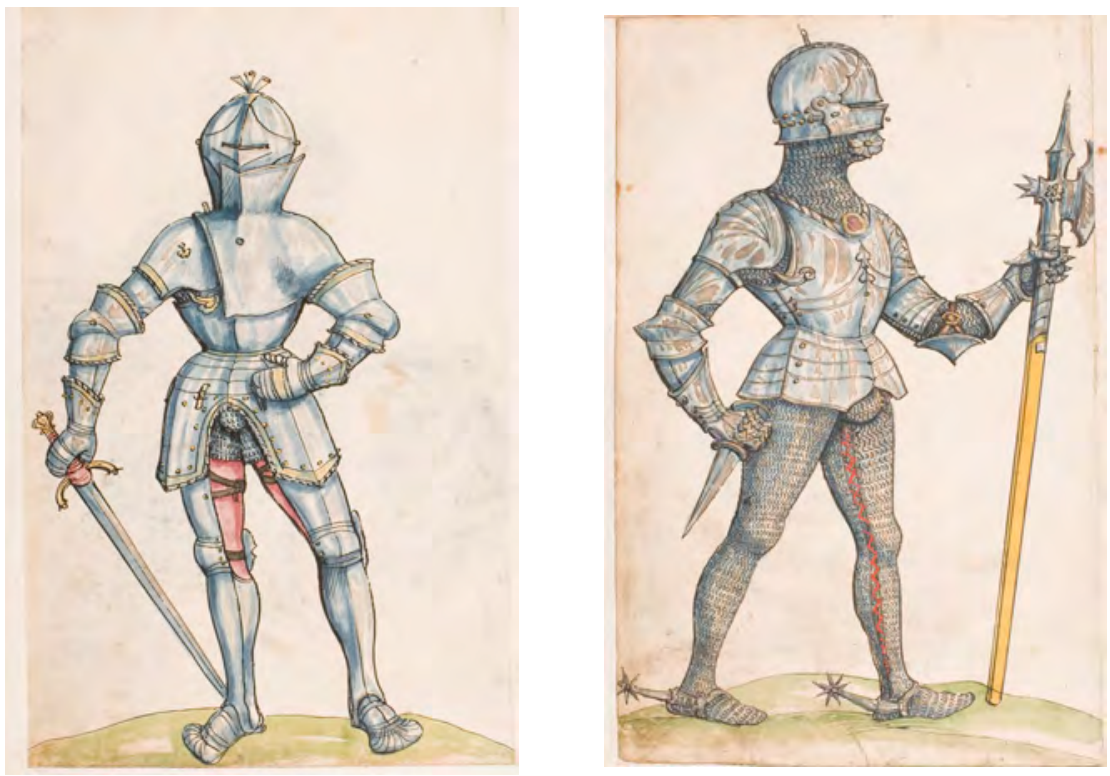

Fig. 20 (left): Artist A, Thun Hohenstein Album, folio 9v, Armour for the Freiturnier (Free Tournament) of 1515-20, 1540s.

Fig. 21: Artist A, Thun-Hohenstein album, folio 12v, figure armoured in the style of 1495for the tournament on foot, 1540 s.

Between the opening of folios $10 \mathrm{v}$ and $11 \mathrm{r}$, with its six pairs of fight-book-inspired fighters, and the meticulous depiction of armoured combatants on folio $12 \mathrm{r}$, a third fifteenth-century image (fig. 22) depicts three standing soldiers clad in stylized versions of elegant late gothic field armour. This drawing has been glued to folio 11r, formed by the verso of the preceding opening. Brown gall ink articulates the soldiers' gracefully swaying figures and strikingly expressive faces. Grisaille washes evoke the volumes of

\footnotetext{
77 For a discussion of the mail chausses represented in this image, published prior to the rediscovery and dating of the Thun album, La Rocca, "Notes on the Mail Chausse," 79-80.
} 
their armoured bodies. Along the page's trimmed left edge, a man leans away from the picture plane; his back turns toward the viewer and exposes the back sides of his pauldrons as they cascade over the raised, linear decoration of his backplate. This soldier extends his preternaturally long leg, revealing the hinges that close his cuisses and greaves, as well as the protective wings of his poleyns, or knee cops. A visored sallet protects his head, and a bevor covers his chin. This figure, whose back is turned to the viewer, leans on a spear as he grasps a barely visible sword in his left hand, carelessly resting its point on the ground. He seems to be in conversation with the image's central figure, whose sallet has no visor, but is crowned with a tall plume. The man holds a lance from which a banner flutters, but his gauntleted hand seems to grasp only air; the lance, apparently added after the rest of the drawing was composed, dissolves into transparency as its shaft meets the more substantial figure.

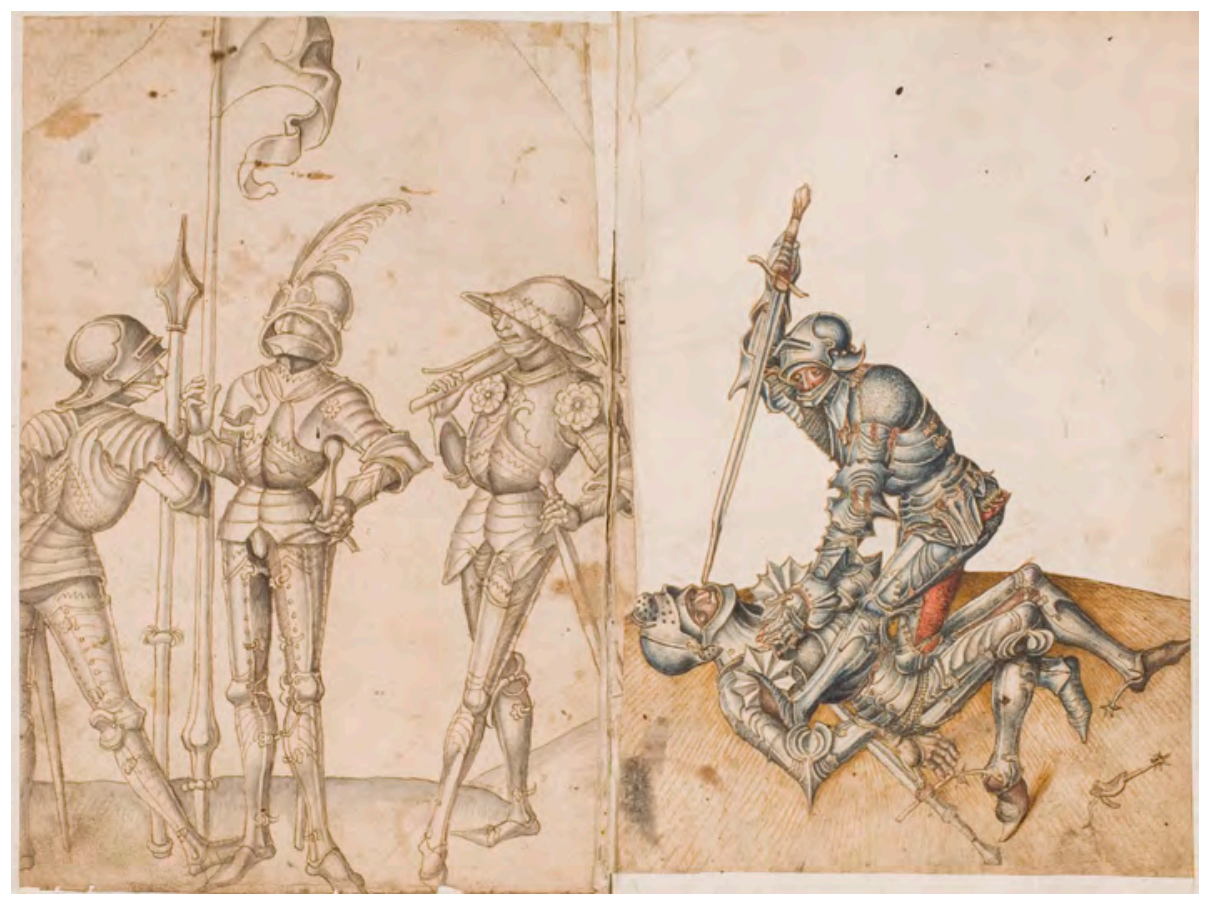

Fig. 22: Unknown Artists, Thun-Hohenstein Album, Prague, Umèleckoprimyslové museum v Praze, GK 11.572-B, folios $11 v$ and $12 r$

The central soldier's frontal pose offers a glimpse of his eyes and nose above the bevor that covers his chin and throat, but that seems strangely unattached to his breastplate. Similarly, his body armour is both stylized and illusionistic. The lance-rest bolted to his right side and the buckled straps that close his cuisses and greaves around his thighs and calves were clearly inspired by the details of real late fifteenth-century armours. However, the jagged forms that adorn the surfaces of his protective plates fall short of evoking the 
decorative punch work and finely formed edges of the articulated steel lames, or overlapping sheets, that made large pieces of plate armour flexible.

The drawing's right edge has also been trimmed, and the corner of the right-hand figure's elbow creeps across the gutter and onto the surface of the facing page, folio 12r. The soldier on the right wears a brimmed war hat, similar to those worn by the light cavalrymen who charge across the preceding opening; cross-hatched marks traverse the brim, perhaps intended to evoke the chased, etched, or painted decoration that often adorned helms during the period. The man nonchalantly holds a crossbow over his right shoulder and smiles beneath the brim of his helmet. The bowman's body armour is elaborate. The edge of his plackart, the reinforcing plate that covers the belly of the breastplate, is delineated by a fleur de lys. He wears besagews-steel roundels that reinforced the pauldrons or protected the armpits when worn with spaulders, or smaller shoulder plates-whose floral, cusped form was popular among armourers north of the Alps throughout the late fifteenth century.

This trio of armoured soldiers, with their various weapons, parallel the groups of armoured soldiers and men-at-arms who made up fifteenth-century armies. For instance, the ordinances of the Burgundian army under Duke Charles the Bold expressly describe the centrality of armoured, lance-wielding heavy cavalry; indeed, each nine- or ten-man unit was called a "lance," after the heavily armoured knight or man-at-arms who fulfilled this leadership role. In the Burgundian configuration, the lancer was supported by one or two armoured pages or servants, three mounted archers, a crossbowman, a handgunner, and a pikeman. ${ }^{78}$ Indeed, the animated style of the three soldiers who populate folio $11 \mathrm{r}$ of the Thun album echoes the individual figures who form far denser arrays in a series of engraved images of Burgundian companies by Master WA.

Although they appear jovial, the trio of soldiers evokes the pitched battlefield beyond the practice rounds of the fencing school or the circumscribed arenas of the judicial duel. Thus, they suggest the most bellicose deployment of the martial knowledge contained in the fight books that inflect the images that surround them. Together with the two other fifteenth-century drawings that comprise the codicological interlude between the album's first and second quires, this inserted image unites the album's later depictions of the armoured body with pictorial antecedents. Furthermore, this set of images draw attention to the bellicose material culture and martial exploits in which the represented armours that fill the album participated. In this way, the fifteenth-century interlude suggests the anonymous compiler's horizons of knowledge to which the album's collected depictions of empty armours and armoured bodies belong.

78 Vale, War and Chivalry, 122-124; Marti et al., Splendour of the Burgundian Court, 322-23. 


\section{CONCLUSION}

The pictorial connections that tie the Thun album's fifteenth-century drawings to the fight book tradition highlight the ways that the visual languages of martial treatises operated well beyond the realm of the Fechtbuch. As fight books themselves invested images with didactic meaning and mnemonic power that prompted viewers to recall systems of movement and strategy, imagery derived from the genre could evoke the martial knowledge that its forms originally conveyed. Art historical consideration of fight book imagery not only exposes the ways that book painters established pictorial strategies for constructing meaning and prompting remembrance of skill. Through works like the Art of Knightly Defense and the many volumes collected or commissioned by Paulus Hector Mair, the fight book tradition also encouraged Augsburg artists from the 1490s through the sixteenth century to develop innovative approaches to representing the armoured body and the material culture of the battle, the duel, the tournament, and the fencing school. These artistic innovations point to the significance of fight books as not only sources for historians of the martial arts, but also sites of pictorial invention and stylistic transmission. They are illustrated not with transparent reflections of real fighters' maneuvers, but with highly constructed representations of both gestures and ideas that could operate independently even when unmoored from their textual contexts.

Identification of the original contexts or antecedents of the earliest Thun drawings exposes aspects of the album's unknown compiler's body of source material, which, in turn, hints at what associations he was seeking to evoke in constructing the collection. The album's juxtaposition of fifteenth-century fight book imagery alongside the trio of soldiers and the later drawings that fill the album invites appreciation of the ties that bound the Augsburg book industry to martial literature and encourages consideration of the connections between the armours on the surrounding pages and their contexts of use. The mnemonic potential of fight book imagery binds the fifteenth-century drawings to the broader commemorative themes that emerge from the album's structure, which are themselves rooted in bellicose identities cultivated at the Habsburg court and in the imperial city of Augsburg.

\section{BIBLIOGRAPHY}

\section{V.1. Primary Sources}

Anonymous, Gladiatoria, circa 1430 (Vienna, Kunsthistorisches Museum, Inv. KK 5013)

Anonymous Augsburg Artists, Inventario Illuminado of Charles V, 1544-1558 (Madrid, Real Armería, N.18)

Anonymous Augsburg Artists, Thun-Hohenstein Album (Imagines Catafractorum), compiled early seventeenth century (Prague, Uměleckoprůmyslové museum v Praze, inv. GK 11.572-B) 
Anonymous Augsburg Artists, Thun-Hohenstein Album (2), compiled early seventeenth century (Prague, Uměleckoprůmyslové museum v Praze, inv. GK 11.572-A)

Anonymous, Ritterspiele gehalten von Kaiser Friedrich III. und Kaiser Maximilian I. 1489-1511, circa 1540s-1550s (Bayerisches Staatsbibliothek, Munich, Cod. Icon 398)

Anonymous, Ritterspiele gehalten von Kaiser Friedrich III. und Kaiser Maximilian I. 1489-1511, circa 1540s-1550s (Augsburg, Universitätsbibliothek Augsburg, Cod. I.6.4.1)

Anonymous (Baumann?), Fecht- und Ringbuch (Codex Wallerstein), circa 1420s and 1460s (Augsburg, Univeritätsbibliothek Augsburg. Cod. I.6.4.2)

Anonymous, $W$ alpurgis Fechtbuch, circa 1320s (Leeds, Royal Armouris, MS I. 33), images available online: $<$ https://collections.royalarmouries.org/archive/rac-archive391002.html> accessed 20.04.2015

Peter Falkner, Kunst zu Ritterliche Were, circa 1491-1495 (Vienna, Kunsthistorisches Museum, Inv. KK 5012)

Johannes Hartlieb, published by Anton Sorg, The History of Alexander the Great (Die Histori von dem grossen Allexander), 1478 (Washington D.C., Library of Congress, Incun.1478. L4), online < https://www.loc.gov/item/48036564/> accessed 23.01. 2018

Paulus Kal, Fechtbuch for Ludwig of Bavaria, circa 1470 (Munich, Bayerisches Staatsbibliothek, Cgm 1507)

Hans Lecküchner, Kunst des Messerfechtens, 1478 (Heidelberg, Universitätsbibliothek Heidelberg, MS. Cod. Pal. Germ. 430)

Paulus Hector Mair, anonymous notaries and collective Appraisers, Confession, Court Records, Inventories, and Sales-Records of Paulus Hector Mair, November 1579May 1580 (Augsburg, Stadtarchiv, Urgichten K262, 1579-80)

Paulus Hector Mair and Jörg Breu the Younger, Sammelband, circa 1542 (Augsburg, Univeritätsbibliothek Augsburg, Cod. I.6.2.4)

Paulus Hector Mair (compiler), Augsburger Fechtordnung, Frankfurter Fechtbruderschaft, Johannes Liecbtenauer: Kunst des langen Schwerts, circa 1540s (Augsburg, Univeritätsbibliothek Augsburg, Cod. I.6.2.5)

Paulus Hector Mair, Geschlechterbuch der Stadt Augsburg, 1548-1550. (Munich Bayerisches Staatsbibliothek, Cod. Icon 312b)

Paulus Hector Mair, Opus Amplissimum de Arte Athletica, circa 1545-55 (Munich, Bayerisches Staatsbibliothek, Cod. Icon 393a-b)

Paulus Hector Mair, Opus Amplissimum de Arte Atbletica, circa 1545-1555 (Vienna, Österreichische Nationabiblithek, Codices 10825-10826)

Paulus Hector Mair, Opus Amplissimum de Arte Atbletica, circa 1545-1555 (Dresden, Sächsische Landesbibliothek -Staats- und Universitätsbibliothek, Mscr. Dresd. C. 94)

Hans Talhoffer, Fecbtbuch for Eberhardt of Württemberg, 1467 (Munich, Bayerisches

Staatsbibliothek, Cod. Icon 394a)

Hans Talhoffer, Fechtbuch, 1459 (Copenhagen, Det Kongelige Bibliotek, MS Thott.290.2) 
Hugo von Trimburg, Der Renner, last quarter of the fifteenth century (New York, Morgan Library, M.763)

Jörg Wilhalm, Draft Fecbtbuch, circa 1520 (Augsburg, Univeritätsbibliothek Augsburg, Cod. I.6.4.5)

Jörg Wilhalm, Fecbtbuch, circa 1522 (Augsburg, Univeritätsbibliothek Augsburg. Cod. I.6.2.3)

\section{V.2. Secondary Sources}

Anglo, Sydney, "Sword and Pen: Fencing Masters and Artists," in The Noble Art of the Sword: Fashion and Fencing in Renaissance Europe 1520-1630, ed. By Tobias Capwell (London: Wallace Collection, 2012), 150-163

- The Martial Arts of Renaissance Europe (New Haven and London: Yale University Press, 2000)

Baptiste, Nicolas, "L'armure et ses typologies: Étude comparée des représentations et des objects," in L'art Chevaleresque du combat: Le maniement des armes à travers les livres de combat (Xiv-Xvt siécles), edited by Daniel Jaquet (Neuchâtel: Alphil, Presses Universitaires Suisses, 2012), 119-152

Bodemer, Heidemarie, "Das Fechtbuch: Untersuchungen zu Entwicklugsgeschichte der bildkünstlerischen Darstellung der Fechtkunst in den Fechtbüchern des Mediterranen und westeuropäischen Raumes vom Mittelalter bis Ende des 18. Jahrhunderts," (unpublished doctoral dissertation, University of Stuttgart, 2008)

Burkart, Eric, "The Autograph of an Erudite Martial Artist: A Close Reading of Nuremberg, Germanisches Nationalmuseum, Hs. 3227a," in Late Medieval and Early Modern Fight Books: Transmission and Tradition of Martial Arts in Europe $\left(14^{\text {th }}-17^{\text {th }}\right.$ Centuries), ed. by Daniel Jaquet, Karen Verelst, and Timothy Dawson, History of Warfare, 112 (Leiden and Boston: Brill, 2016), 451-480

Briquet, C. M., Les filigranes: Dictionnaire historique des marques du papier dès leur apparition vers 1282 jusqu'en 1600 (Mansfield Center: Martino, 2007)

Bynum, Caroline Walker, Christian Materiality: An Essay on Religion in Late Medieval Europe (New York and Cambridge: Zone Books, Distributed by the MIT Press, 2011)

Capwell, Tobias, David Edge, and Jeremy Warren, Masterpieces of European Arms and Armour in the Wallace Collection (London: Wallace Collection; Holberton Publishing, 2011)

Cuneo, Pia F, "Introduction." In Artful Armies, Beautiful Battles: Art and Warfare in Early Modern Europe, edited by Pia F. Cuneo. History of Warfare, XII (Leiden and Boston: Brill, 2002)

Dackerman, Susan, Painted Prints: The Revelation of Color in Northern Renaissance \& Baroque Engravings, Etchings \& Woodcuts (University Park: Pennsylvania State University Press, 2002) 
Fabian, Claudia and Claudia Bubenik, Die Fugger im Bild: Selbstdarstellung einer

Familiendynastie der Renaissance: Begleitbuch zur Schatzkammerausstellung anlässlich der Erwerbung des Ehrenbuchs der Fugger (Cgm 9460) und der Fuggerorum et Fuggerarum Imagines (Cod. Icon. 380) (Luzern: Quaternio, 2010)

Forgeng, Jeffrey L, "Owning the Art: The German Fechtbuch Tradition," in The Noble Art of the Sword: Fashion and Fencing in Renaissance Europe 1520-1630, ed. by Tobias Capwell (London: The Wallace Collection, 2012), 164-176

, "The Martial Arts Treatise of Paulus Hector Mair," in Die Kunst des Fechtens, ed. by Elisabeth Vavra and Matthias Johannes Bauer (Heidelberg: Universitätsverlag Winter, 2017), 267-283

- The Medieval Art of Swordsmanship: A Facsimile and Translation of Europe's Oldest Personal Combat Treatise, Royal Armouries Ms I.33 (Union City and Leeds: The Chivalry Bookshelf in partnership with the Royal Armouries, 2003)

Friedhuber, Inge, “Der 'Fuggerische Ehrenspiegel' als Quelle zur Geschichte Maximilians I. Ein Beitrag zur Kritik der Geschichtswerke Clemens Jägers und Sigmund von Birkens," Mitteilungen des Instituts für Österreichische Geschichtsforschung 81, no. 1-2 (1973), 101-138

Gamber, Ortwin, "Der Turnierharnisch zu Zeit König Maximilians I und das Thunsche Skizzenbuch," Jabrbuch der Kunsthistorischen Sammlungen in Wien 53, no. 1 (1957), 33-70

Groebner, Valentin, Defaced: The Visual Culture of Violence in the Late Middle Ages (New York, Cambridge: Zone Books; Distributed by the MIT Press, 2004)

Hagedorn, Dierk, and Barolomiej Walczak, Gladiatoria: New Haven Ms U860.F46 1450 (Herne: Torsten Verhülsdonk, 2015)

Hils, Hans-Peter, Meister Johann Liechtenauers Kunst des langen Schwertes, Europäische Hochschulschriften, 257 (Frankfurt am Main: Peter Lang, 1985)

Huber, Daniel J.M., Marx Walthers Turnierbuch mit Familienchronik und Stiftungsverzeichnis. (Königsbrunn: Theuerdank Verlag, 2014)

Jaquet, Daniel, "Die Kunst des Fechtens in den Fechtschul," in Agon und Distinktion: Soziale Räume des Zweikampfs zwischen Mittelalter und Neuzeit, edited by Uwe Israel and Christian Jaser (Berlin: Lit-Verlag, 2016), 243-257

, "Introduction," in L'art chevaleresque du combat: le manierment des armes à travers les livres de combat (Xiv'-Xvi siécles), edited by Daniel Jaquet (Neuchâtel: Alphil, Presses Universitaires Suisses, 2013), 15-23

Kirchhoff, Chassica, “Armors’ Afterlives: The Late Medieval Martial Body in the Early Modern Imaginary,” Medieval Culture and War Conference, Lisbon, 22-24 June 2017

Krause, Katharina, Hans Holbein der Ältere. Kunstwissenschaftliche Studien (Munich: Deutscher Kunstverlag, 2002)

Krause, Stefan and Christoph Kaindel, "Das Große Kartenspiel des Meisters E.S.Frühe gedruckte Fechtdarstellungen,” W affen- und Kostümkunde 2013, 1 (2013), 1-18 
Kusudo, Kazuhiko, "P.H. Mair (1515-1579): A Sports Chronicler in Germany," in Sport and Culture in Early Modern Europe, ed. by John McClelland and Brian Merillees (Toronto: Centre for Reformation and Renaissance Studies, 2009), 337-354

La Rocca, Donald J., "Notes on the Mail Chausse." The Journal of the Arms and Armour Society XV (September 1995), 69-84

Leitner, Quirin Ritter von, “Artistisches Quellenmaterial aus der Gräfl. ThunHohenstein'schen Fideicommiss-Bibliothek in Tetschen," Jabrbuch der Kunsthistorischen Sammlungen der Allerböchsten Kaiserbauses 7, no. 2 (1888), 1-6

Leng, Rainer, Ars Belli: Deutsche Taktische Und Kriegstechnische Bilderhandschriften Und Traktate Im 15. Und 16. Jabrbundert, 2 vols, Imagines medii aevii, 12 (Weisbaden: Reichert, 2002)

Mauer, Benedikt, "Sammeln und lesen - drucken und Schreiben. Die vier Welten des augsburger Ratsdieners Paul Hector Mair," in Medien und Weltbilder im Wandel der früben Neuzeit, ed. by Theresia Hörmann, Documenta Augustana (Augsburg: Wißner, 2000), 107-132

Mondschein, Ken, The Knightly Art of Battle, (Los Angeles: J. Paul Getty Museum, 2011)

Müller, Jan-Dirk, "Zwischen Mündlicher Anweisung und schriftlicher Sicherung von Tradition. Zur Kommunikationsstruktur spätmittelalterlicher Fechtbücher," Sitzungberichte um Osterreichische Akademie der Wissenschaften, Philosophisch-Historische Klasses 596, no. 1 (1992), 379-400

Neer, Richard, "Connoisseurship and the Stakes of Style," Critical Inquiry 32 (Autumn 2005), 1-26

Reitzenstein, Alexander Freiherr von, "Das Thun'sche Plattnerbuch a/2," Waffen- und Kostümkunde: Zeitschrift der Gesellschaft für Historische Waffen- und Kleidungsgeschichte 2, no. 2 (1960), 88-95

Terjanian, Pierre, "The Art of the Armorer in Late Medieval and Renaissance Augsburg: The Rediscovery of the Thun Sketchbooks," Jabrbuch des Kunsthistorischen Museums Wien 13/14 (2013), 298-395

, "The Art of the Armorer in Late Medieval and Renaissance Augsburg: The Rediscovery of the Thun Sketchbooks (Part II)," Jabrbuch des Kunsthistorischen Museums Wien 17/18 (2017) 9-112.

Tobler, Christian Henry, Captain of the Guild: Master Peter Falkner's Art of Knightly Defense, (Wheaton: Freelance Academy Press, 2012)

Vale, Malcolm, War and Chivalry: Warfare and Aristocratic Culture in England, France, and Burgundy at the End of the Middle Ages (Athens: The University of Georgia Press, 1981)

Verboven, Koenraad, Myriam Carlier, and Jan Dumolyn, "A Short Manual to the Art of Prosopography," in Prosopography Approaches and Applications, A Handbook, ed. by K.S.B. Keats, Prosopographica et Genealogica (Oxford: Oxford University Press, 2007) 
